\title{
Carbon Dioxide Emissions from Subaerial Volcanic Regions
}

\author{
Two Decades in Review \\ CYNTHIA WERNER, TOBIAS P. FISCHER, ALESSANDRO AIUPPA, \\ MARIE EDMONDS, CARLO CARDELLINI, SIMON CARN, \\ GIOVANNI CHIODINI, ELIZABETH COTTRELL, MIKE BURTON, \\ HIROSHI SHINOHARA, AND PATRICK ALLARD
}

\subsection{Introduction}

Volcanism and metamorphism are the principal geologic processes that drive carbon transfer from the interior of Earth to the surface reservoir. ${ }^{1-4}$ Input of carbon to the surface reservoir through volcanic degassing is balanced by removal through silicate weathering and the subduction of carbon-bearing marine deposits over million-year timescales. The magnitude of the volcanic carbon flux is thus of fundamental importance for stabilization of atmospheric $\mathrm{CO}_{2}$ and for long-term climate. It is likely that the "deep" carbon reservoir far exceeds the size of the surface reservoir in terms of mass, ${ }^{5,6}$ more than $99 \%$ of Earth's carbon may reside in the core, mantle, and crust. The relatively high flux of volcanic carbon to the surface reservoir, combined with the reservoir's small size, results in a short residence time for carbon in the ocean-atmosphere-biosphere system ( 200 ka) ${ }^{7}$ The implication is that changes in the flux of volcanic carbon can affect the climate and ultimately the habitability of the planet on geologic timescales. In order to understand this delicate balance, we must first quantify the current volcanic flux of carbon to the atmosphere and understand the factors that control this flux.

The three most abundant magmatic volatiles are water $\left(\mathrm{H}_{2} \mathrm{O}\right)$, carbon dioxide $\left(\mathrm{CO}_{2}\right)$, and sulfur (S), with $\mathrm{CO}_{2}$ being the least soluble in silicate melts. ${ }^{8}$ For this reason, it is not only Earth's active volcanoes that are a source of magmatic $\mathrm{CO}_{2}$, but also numerous inactive volcanoes with magma bodies present at depth in the crust that contribute to the carbon emissions (Figure 8.1). Emissions from active volcanoes are released through crater fumaroles and open vents to form visible volcanic plumes, but diffuse degassing and degassing through springs on the volcano flanks also contribute to the total flux of carbon from a volcano. Plume gas emissions typically dominate over flank gas emissions and are highest during periods of eruptive activity. ${ }^{9}$ Due to the hazard associated with eruptions and the value of volcanic gas monitoring to aid in eruption forecasting, much of our knowledge about the degassing of volcanic systems comes from active volcanoes, and typically during periods of unrest.

At less active and dormant (i.e. inactive) volcanoes, magmatic emissions of $\mathrm{CO}_{2}$ are less obvious. $\mathrm{CO}_{2}$ emissions are typically highest in thermal areas where gases are emitted through small fumaroles, soils, and fractures as diffuse degassing and through hot and cold 


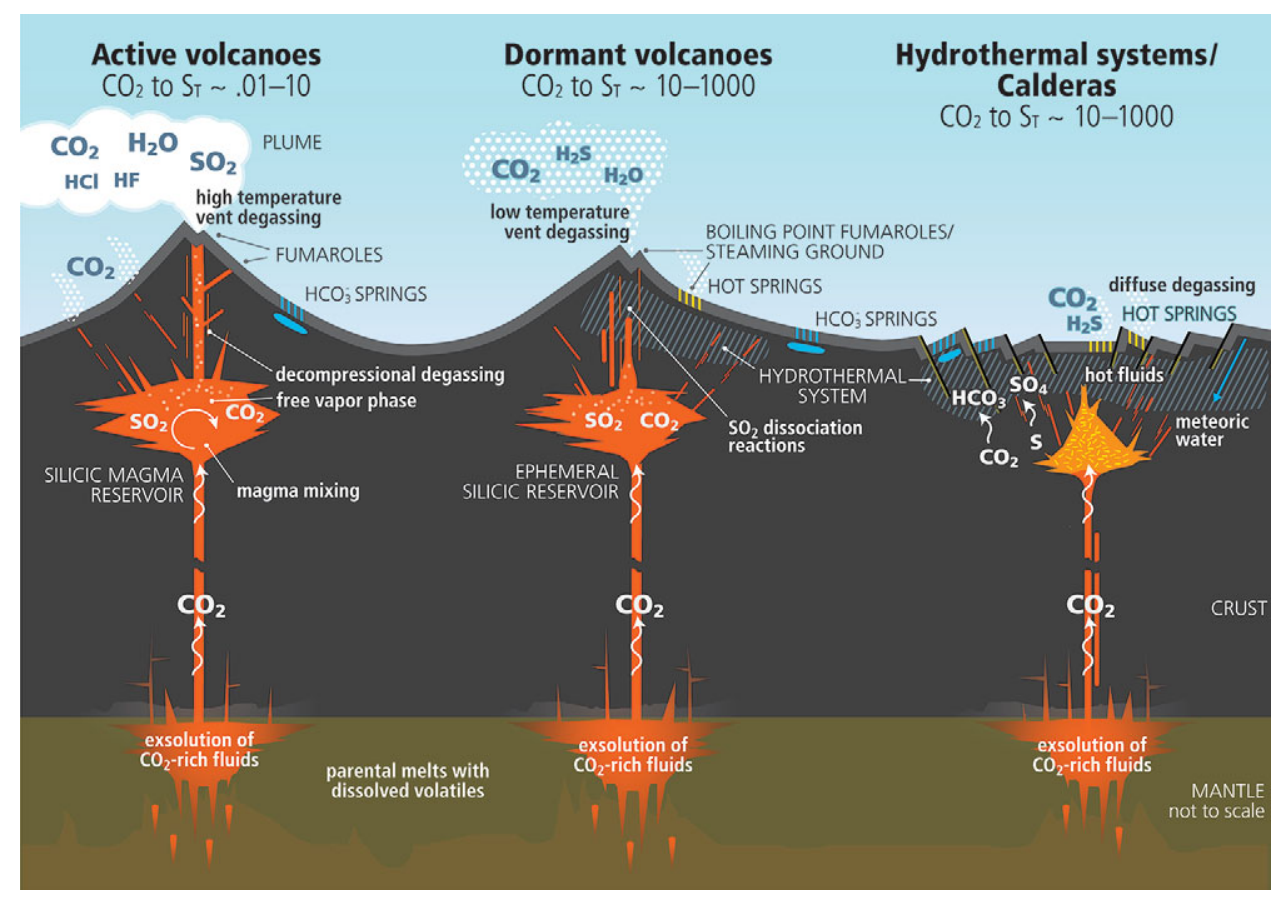

Figure 8.1 Conceptual models showing typical $\mathrm{CO}_{2}$ emission patterns from volcanic and magmatic systems. $\mathrm{CO}_{2}$ may be sourced from magma bodies deep in the crust, whereas other volatiles may remain largely dissolved in magma until much shallower depths. Visible plumes are typical for active volcanoes, whereas $\mathrm{CO}_{2}$ degassing from dormant/inactive volcanoes and hydrothermal systems is less obvious. Low-temperature degassing may or may not result in a visible plume even when $\mathrm{CO}_{2}$ is present. Significant quantities of $\mathrm{CO}_{2}$ are emitted from areas of diffuse degassing, and $\mathrm{CO}_{2}$ also reacts with groundwater.

springs. Occasionally, older volcanic areas can also exhibit cold degassing of $\mathrm{CO}_{2} \cdot{ }^{10} \mathrm{CO}_{2}$ is denser than air, and therefore an asphyxiation hazard can exist in low-lying areas. Visual indicators of $\mathrm{CO}_{2}$ release include thermally perturbed or bare ground and the odor of $\mathrm{H}_{2} \mathrm{~S}$. Atmospheric plumes of $\mathrm{CO}_{2}$ can also form in such areas, even if a region is not thermal, ${ }^{11}$ and these emissions may not be visible. Additional contributions of volcanic carbon can be found in groundwaters, ${ }^{12,13}$ but globally this contribution is less well studied compared to gas emissions.

In this chapter, we review recent advances in our understanding of the flux of $\mathrm{CO}_{2}$ emitted in subaerial volcanic areas and how these emissions vary in space and time. Carbon released through mid-ocean ridges (MORs) and other oceanic environments is reviewed in Chapter 9. Through the focused efforts funded by the Deep Carbon Observatory and the Deep Earth CArbon DEgassing (DECADE) research initiative, ${ }^{14}$ there is now greater global coverage of subaerial volcanic areas emitting $\mathrm{CO}_{2}$ compared to previous efforts. ${ }^{15}$ $\mathrm{CO}_{2}$ emission rates have now been quantified for many of the most active volcanoes, and 
some in real time. New observations reveal how the volcanic carbon flux varies through time and between different volcanic settings. Here, we discuss the nature of these emissions in terms of their magnitude, relationship to eruptive activity, and temporal variability, as well as how such measurements may enhance our ability to forecast eruptive activity.

Techniques to quantify diffuse and plume $\mathrm{CO}_{2}$ emissions (in the absence of $\mathrm{SO}_{2}$ ) were only developed in the mid-to-late $1990 \mathrm{~s} ;{ }^{16,17}$ we are now approaching two decades of routine measurements for some of the world's volcanic areas. Where monitoring has been frequent, data allow decadal-scale evaluations of the output from a number of the most prolific carbon-emitting volcanic regions. We discuss the magnitude of emissions from some of the largest diffuse degassing regions and the challenges in extrapolating diffuse measurements globally.

We review the advances in understanding the sources of carbon outgassing from volcanoes, showing how the isotopic signature of carbon and other species has allowed distinction of the carbon contribution from subducting slabs, the crust, and mantle sources on arc scales. These insights into magmatic-tectonic controls on carbon outgassing then allow us to begin to link the modern volcanic carbon outgassing picture to that which might have existed in the geological past.

\subsection{Methods for Measuring Volcanic $\mathrm{CO}_{2}$ : Established Techniques and Recent Advances}

The principal challenges in the measurement of $\mathrm{CO}_{2}$ from volcanic regions are related to the detection of volcanic $\mathrm{CO}_{2}$ over the atmospheric background, logistical difficulties associated with accessing gas plumes, and technical issues that accompany deployment of instruments in the field. Techniques to measure $\mathrm{CO}_{2}$ emission rates from different types of sources and the related uncertainties in these measurements have been reviewed previously. ${ }^{15}$ Here, we expand on aspects of these methods as they pertain to information presented here and review emerging techniques and measurement biases.

\subsubsection{Measurements of $\mathrm{CO}_{2}$ Emissions in Volcanic Plumes}

Volcanoes that are most active display persistent gas emissions during either frequent eruptions or as "passive" degassing of shallow magma bodies. ${ }^{18}$ These volcanoes typically produce a volcanic plume, measurable with either direct or indirect techniques. The indirect or ratio technique underpins much of the recent progress in the measurement of volcanic $\mathrm{CO}_{2}$ emission rates. Here, the $\mathrm{SO}_{2}$ emission rate is measured using ultraviolet (UV) spectroscopy either from the ground, ${ }^{19}$ airborne, ${ }^{20,21}$ or space-based platforms, ${ }^{22}$ and then multiplied by the $\mathrm{C} / \mathrm{S}$ mass ratio determined by fumarole sampling, ${ }^{8}$ Fouriertransform infrared (FTIR) spectroscopy, ${ }^{23}$ or Multi-GAS measurements ${ }^{24,25}$ and the plume speed. Indirect techniques rely on reliable and representative $\mathrm{SO}_{2}$ emissions and $\mathrm{C} / \mathrm{S}$ data. Uncertainties in the $\mathrm{SO}_{2}$ flux (e.g. due to in-plume light scattering) can produce a bias to 
lower $\mathrm{SO}_{2}$ fluxes by a factor of two or more. ${ }^{26,27}$ Uncertainties in the C/S ratio of the gas arise from calibration of the Multi-GAS at a different altitude from the measurements, variable sensor response times to $\mathrm{CO}_{2}$ and $\mathrm{SO}_{2},{ }^{28-30}$ low plume concentrations (close to detection limits), and poorly mixed plumes. ${ }^{31}$

Direct measurements of $\mathrm{CO}_{2}$ plumes use an airborne platform to measure the vertical profile of $\mathrm{CO}_{2}$ concentration in the atmosphere downwind of the volcanic vent. The volcanic $\mathrm{CO}_{2}$ (in excess of atmospheric background) is multiplied by the plume speed to derive an emission rate. ${ }^{17,32,33}$ Uncertainties in plume speed affect both measurement types and vary greatly depending on whether the speed is estimated from radiosonde or weather models or is measured on site. Direct $\mathrm{CO}_{2}$ measurement is the only option for the quantification of plume emissions where $\mathrm{SO}_{2}$ is not present. ${ }^{34}$ In-plume concentrations of 2-5 ppm above background are typically needed, depending on the $\mathrm{CO}_{2}$ analyzer used, and $\sim 10-50 \mathrm{t} / \mathrm{d}$ is a reasonable detection limit for airborne measurements depending on the aircraft, plume speed, and distance from the vent. Emissions less than this range or in areas where airborne measurements are not feasible are challenging to quantify and represent a recognized gap in current budgets. Future approaches to such challenging field measurements will include use of miniaturized IR (and other) sensors on drones ${ }^{35-37}$ and groundbased light detection and ranging (LIDAR). ${ }^{38,39}$

\subsubsection{Diffuse $\mathrm{CO}_{2}$ Emissions and Groundwater Contributions}

Many volcanic systems support areas of diffuse degassing often associated with hydrothermal activity due to magmatic intrusions at depth. A common method of quantifying diffuse emissions through soils is the accumulation chamber technique, ${ }^{16,40}$ where a chamber is set on the ground and the concentration of the accumulated $\mathrm{CO}_{2}$ is measured with time. Here, point measurements of the flux of $\mathrm{CO}_{2}$ are made over an area of interest and total emissions are quantified by applying geostatistical techniques (see Refs. 16, 41 and references therein). The same chamber technique can be applied to lakes. ${ }^{42,43}$ Eddy covariance (EC) is an aboveground technique that has been used successfully to measure the flux of $\mathrm{CO}_{2}$ derived from diffuse, fumarole, and pool sources in regions with relatively low topographic relief. ${ }^{44-47}$ The EC footprint (the source area on the ground contributing to the measured $\mathrm{EC} \mathrm{CO}_{2}$ flux) varies with atmospheric conditions such as wind speed and direction and is typically smaller than most degassing regions. Thus, to determine the $\mathrm{CO}_{2}$ emission rate from a region of interest requires assumptions about the representativeness of the average EC flux to the larger area. ${ }^{48}$ Alternatively, months-long deployments and inverse modeling have also been used to determine emission rates, ${ }^{47,49}$ though such models also have inherent uncertainty. While promising for long-term hazard monitoring, more work is needed for utilizing the full potential of EC for determining emission rates.

In volcanic areas, $\mathrm{CO}_{2}$ also dissolves into groundwaters and can emit through springs as a dissolved constituent. This flux can be quantified through chemical sampling and stream gauging, ${ }^{12,50}$ or through mass balance of the aquifer (i.e. coupling hydrogeological and 
hydrogeochemical data). For instance, using this technique, the amount of $\mathrm{CO}_{2}$ transported by Vesuvio groundwaters was estimated at about $150 \mathrm{t} / \mathrm{d}$, or in the same order of magnitude as the diffuse emission of $\mathrm{CO}_{2}$ in the crater area. ${ }^{13}$

\subsubsection{Significant Recent Advances: Continuous and Remote Techniques}

One major advance toward producing robust long-term records of volcanic $\mathrm{CO}_{2}$ emissions has arisen from the advent of autonomous Multi-GAS instruments. ${ }^{51}$ When combined with independent $\mathrm{SO}_{2}$ flux time series, ${ }^{52}$ measurements from these instruments have refined the $\mathrm{CO}_{2}$ output for several volcanoes, characterizing the variability of emissions on temporal scales of days to years for the first time. ${ }^{53-57}$ Multi-GAS stations are being adapted for deployment at high-latitude volcanoes ${ }^{28,30,58}$ and can perform automated calibrations for improved accuracy. ${ }^{28,48}$ Multi-GAS has recently been used on manned airborne missions and on unmanned aerial vehicles (UAVs). ${ }^{35,37,59}$ Overall, these measurements are fundamentally changing the way volcanic hazard is evaluated at active volcanoes.

Techniques to quantify $\mathrm{CO}_{2}$ remotely and from smaller features have also developed in recent years. Tunable diode laser spectrometer ${ }^{60-62}$ measurements have shown that the $\mathrm{CO}_{2}$ output from fumaroles is significant (hundreds of $\mathrm{t} / \mathrm{d}$ ) at some volcanoes, illustrating a nontrivial contribution to the volcanic $\mathrm{CO}_{2}$ flux from this largely unquantified source at a global scale. In addition, LIDAR, specifically differential absorption LIDAR, ${ }^{38,63}$ the smaller $\mathrm{CO}_{2}$ differential absorption LIDAR, ${ }^{39}$ and miniaturized light laser sensing spectrometers, ${ }^{64}$ have been used to determine path-integrated $\mathrm{CO}_{2}$ concentrations over kilometer scales. While these studies offer new prospects for quantifying $\mathrm{CO}_{2}$ flux, further work is required to standardize and widen their potential applications.

Advances have been made with satellite remote sensing of $\mathrm{CO}_{2}$, although $\mathrm{CO}_{2}$ is among the most challenging volcanic gases to detect due to high atmospheric concentrations ( $\sim 00 \mathrm{ppm}$ and rising due to anthropogenic contributions) that dominate the signal of column-average measurements. Even at some of the strongest volcanic gas sources (e.g. Etna, Italy), the volcanic $\mathrm{CO}_{2}$ signal may be only up to tens of ppm above background, ${ }^{21,65}$ requiring high precision and accuracy for detection from space. NASA's Orbiting Carbon Observatory 2 (OCO-2), with a small footprint size $(1.3 \times 2.3 \mathrm{~km})$ and $<0.2 \%$ accuracy, permitted the first reported satellite detection of volcanic $\mathrm{CO}_{2}$ emissions at Yasur volcano in 2015. ${ }^{6}$ However, neither OCO-2 nor the Japanese Greenhouse Gases Observing Satellite (GOSAT) provide sufficient temporal resolution or spatial coverage to be effective volcano monitoring tools. The future of volcanic $\mathrm{CO}_{2}$ monitoring from space is inextricably linked to the politics of greenhouse gas measurements and climate change. Several planned or proposed satellite missions (NASA's OCO-3, JAXA's GOSAT-2, and ESA's CarbonSat) offer the potential for volcanic $\mathrm{CO}_{2}$ detection, but it is unlikely to ever become as routine as volcanic $\mathrm{SO}_{2}$ measurements, and will likely be restricted to "spot" measurements of the strongest persistent volcanic $\mathrm{CO}_{2}$ sources. 


\subsection{Estimating Global Emission Rates of $\mathrm{CO}_{2}$}

Quantifying global emissions of volcanic $\mathrm{CO}_{2}$ is an area of ongoing research that will continue to evolve as more measurements become available. Some of the first estimates of global volcanic $\mathrm{CO}_{2}$ degassing, published in the 1990s, were based on only seven to nine measurements of passive $\mathrm{CO}_{2}$ degassing; ${ }^{67,68}$ our understanding of $\mathrm{CO}_{2}$ degassing in volcanic areas has progressed greatly since then. Here, we review methodologies from recent studies quantifying global volcanic $\mathrm{CO}_{2}$ and how our new understanding may allow us to reduce some of the uncertainties in these estimates.

Until recently, most estimates of global $\mathrm{CO}_{2}$ emissions were determined by proxy where volcanic $\mathrm{CO}_{2}$ was scaled globally by a tracer (e.g. $\mathrm{SO}_{2}$ or ${ }^{3} \mathrm{He}$ ). Work focused on determining the $\mathrm{C} / \mathrm{S}$ ratio of fumaroles based on level of activity ${ }^{69}$ or on an arc-wide basis $^{70}$ and combining these data with global $\mathrm{SO}_{2}$ emission rate compilations. ${ }^{71,72}$ While seemingly straightforward, numerous uncertainties exist in these methods. First, C/S is not constant in time, and it is challenging to discern whether variations in $\mathrm{C} / \mathrm{S}$ reflect changing mixtures of sources (magmatic vs hydrothermal) or progressive degassing of a single magmatic source due to gas loss or decompression (Figure 8.1). ${ }^{73,74}$ Second, $\mathrm{SO}_{2}$ emission rate data are skewed toward easily accessible locations and volcanoes experiencing unrest. Progress has been made with satellite remote sensing data that, when averaged over long time periods, are sensitive enough to measure lower emission rates of $\mathrm{SO}_{2}$, thereby reducing some measurement bias. For example, recent work used Ozone Monitoring Instrument (OMI) satellite data ${ }^{75}$ to calculate a global passive volcanic $\mathrm{SO}_{2}$ flux of $23 \pm 2 \mathrm{Tg} \mathrm{SO}_{2} / \mathrm{yr}$ during the decade 2005-2015 from 91 volcanoes, half of which also have the C/S ratio measured. However, 91 volcanoes only represents $16 \%$ of the 570 volcanoes active in historic time, and $6 \%$ of the volcanoes active in the Holocene, ${ }^{76}$ many of which might be passively degassing $\mathrm{CO}_{2}$, but not emitting $\mathrm{SO}_{2}$ over the satellite detection limit. Some previous global estimates of $\mathrm{CO}_{2}$ emissions have assumed that the strongest emitters of $\mathrm{SO}_{2}{ }^{57}$ also produce the most $\mathrm{CO}_{2}$, but the time frame of measurement is important to consider, as is the number of degassing systems. The temporal distribution of volcanic $\mathrm{CO}_{2}$ outgassing could be very different from that of $\mathrm{SO}_{2},{ }^{77}$ which is dominated by a relatively small number of erupting and persistently degassing volcanoes. Further clarity on this issue may be provided in the near future with the recently launched Tropospheric Ozone Monitoring Instrument (TROPOMI) sensor (www.tropomi.eu), which has 12-times higher spatial resolution than the earlier OMI sensor, and may reveal weaker plumes.

Global ${ }^{3} \mathrm{He}$ fluxes have also been used to estimate global arc $\mathrm{CO}_{2}$ fluxes. ${ }^{78,79}$ The estimated ${ }^{3} \mathrm{He}$ flux from arcs is based on the well-constrained ${ }^{3} \mathrm{He}$ flux from MORs and the assumption that $80 \%$ of volcanic activity on Earth is associated with MORs and the remainder mainly from volcanic arcs. ${ }^{80}$ Intra-oceanic arc magma fluxes were revised ${ }^{81}$ and show a factor of approximately two times higher rates compared to the early studies. ${ }^{80,82}$ While MOR ${ }^{3} \mathrm{He}$ fluxes appear to be quite well constrained within a factor of approximately two, ${ }^{83}$ work on global arc-magma production rates is still sparse, and therefore arc ${ }^{3} \mathrm{He}$ fluxes are likely associated with uncertainties that remain challenging to 
quantify. The most recent volcanic $\mathrm{CO}_{2}$ flux from arcs is estimated to be $22 \times 10^{11} \mathrm{~mol} / \mathrm{yr}$ or $95 \mathrm{Tg} \mathrm{CO} / \mathrm{yr},{ }^{84}$ based on the $\mathrm{CO}_{2} /{ }^{3} \mathrm{He}$ ratio of volcanic gases with outlet temperatures of $>200^{\circ} \mathrm{C}$, although variability in the mantle $\mathrm{CO}_{2}{ }^{\beta} \mathrm{He}$ adds considerable uncertainty to such calculations.

A third approach has been to extrapolate $\mathrm{CO}_{2}$ data based on actual measurements. ${ }^{15,57}$ The latest budget calculation ${ }^{15}$ separated emissions based on the source (plume degassing, diffuse degassing from historically active volcanoes, hydrothermal and inactive areas, volcanic lakes, and MORs) and extrapolated them based on the number of similar systems globally. Roughly $50 \%$ (271 $\mathrm{Tg} \mathrm{CO}_{2} / \mathrm{yr}$ ) of the total global subaerial emission of $\mathrm{CO}_{2}(540$ $\mathrm{Tg} \mathrm{CO}_{2} / \mathrm{yr}$ ) was estimated to come from $\sim 150$ passively degassing volcanoes, based on the average $\mathrm{CO}_{2}$ emissions measured at 33 active volcanic systems. An additional $20 \%$ was estimated by extrapolating observed diffuse emissions to the $\sim 550$ historically active volcanoes. $\mathrm{CO}_{2}$ emissions from hydrothermal systems were treated separately, as were volcanic lakes and MORs.

The two main quantification challenges in extrapolating empirical data include the determination of a representative flux and the estimation of the total number of degassing volcanoes. The Global Volcanism Program (GVP) Volcanoes of the World catalog has been used to assess the number of volcanoes degassing globally, but it is important to note that the catalog quantifies the number of degassing volcanoes (i.e. "fumarolic" volcanoes) only where there has been "no (other) explicit evidence for Holocene eruptive activity." Thus, of the 1545 volcanoes with known or inferred eruptive activity in the Holocene, it is unclear how many are degassing other than those defined as "fumarolic" or "solfataric." In the latest volume, this category has been reduced from over 100 to 64 as more systems now have other data indicating Holocene activity.

Burton et al. ${ }^{15}$ suggested $\sim 150$ volcanoes were degassing today, or $10 \%$ of the $\sim 1500$ volcanoes active in the Holocene. ${ }^{85}$ Satellite measurements show ${ }^{16}$ instead that 91 systems have emitted significant amounts of $\mathrm{SO}_{2}$ (and thus $\mathrm{CO}_{2}$ ) between 2005 and 2015, yet these data are representative of eruptive periods only, as higher-altitude plumes are more readily detected from space. As satellite surveillance of $\mathrm{SO}_{2}$ emissions improves, the number of degassing sources measurable from space will likely increase. Our compilation shows there are now 201 Holocene volcanic systems associated with some form of $\mathrm{CO}_{2}$ degassing observations (Supplemental Tables 8.1 and 8.2) and an additional 22 where the last eruptive activity was in the Pleistocene (Supplemental Table 8.3). Thus, future attempts to estimate global $\mathrm{CO}_{2}$ degassing from volcanic areas should not assume that only historically active or Holocene volcanoes are actively degassing, but also consider the 1325 Pleistocene volcanoes. ${ }^{76}$

\subsection{Current State of Knowledge of $\mathrm{CO}_{2}$ Degassing from Volcanoes}

\subsection{1 $\mathrm{CO}_{2}$ Emissions from Earth's Most Active Volcanoes}

Earth's most active volcanoes are those that are best studied due to the hazards they pose. Over decadal timescales, many of the most active volcanoes alternate between periods of 
strong degassing, typically associated with periods of eruptive activity, and phases of reduced (or arrested) degassing, with the former preferentially targeted by observations. Global $\mathrm{CO}_{2}$ compilations calculate average emissions based on all published estimates of $\mathrm{CO}_{2}$ flux, ${ }^{15,67}$ yet many of these are spot measurements acquired during periods of heightened activity that may span decades. It is therefore likely that combining sparse measurements collected over several decades may lead to an overestimation of the real time-averaged global volcanic $\mathrm{CO}_{2}$ output.

In an attempt to reduce the above uncertainty, the average $\mathrm{CO}_{2}$ fluxes for some volcanoes in Burton et al. ${ }^{15}$ were revised (Supplemental Table 8.1) using more recent observations that have been obtained in the last decade (2005-2017) where available, and including both eruptive and quiescent periods whenever possible. Our revised average fluxes are lower than previously published ${ }^{15}$ for all of the major volcanic $\mathrm{CO}_{2}$ sources (Supplemental Table 8.1). For example, recent observations of $\mathrm{CO}_{2}$ emissions from Nyiragongo volcano are lower by approximately a factor of ten (i.e. $\sim 9300 \mathrm{t} / \mathrm{d},{ }^{86,87}$ compared to $\sim 95,000 \mathrm{t} / \mathrm{d}$ collected during the $1950 \mathrm{~s}-1970 \mathrm{~s}^{15,88}$ ). Similarly, we report a new time-averaged $\mathrm{CO}_{2}$ flux for Miyakejima volcano in Japan $\left(1070 \mathrm{t} / \mathrm{d}^{57}\right)$ based on nearly two decades of systematic observations. This longer data set yields one order of magnitude lower $\mathrm{CO}_{2}$ emissions than implied by the intense degassing unrest of early $2000 .{ }^{89,90}$ Likewise, emission rates from Augustine and Mount Spurr volcanoes are considerably lower than previously estimated when quiescent periods are considered as well as the unrest/eruptive periods that occurred between 2005 and 2015 (Supplemental Table 8.1). ${ }^{65,91-93}$

Our compilation also includes new results for more than 50 volcanoes whose volcanic $\mathrm{CO}_{2}$ fluxes have been quantified for the first time since 2013 (Supplemental Table 8.1), mostly due to the DECADE initiative. ${ }^{14}$ While the number of volcanoes with a measured $\mathrm{CO}_{2}$ plume has more than tripled since 2013 ( $33^{15}$ vs. 102), the total (cumulative) $\mathrm{CO}_{2}$ emitted is roughly two-thirds of the previous estimate (44 $\mathrm{Mt} \mathrm{CO}_{2} / \mathrm{yr}$, or $\mathrm{Tg} / \mathrm{yr}$, vs $59.7 ;^{15}$ Supplemental Table 8.1), largely due to the diminished estimates for the top volcanic $\mathrm{CO}_{2}$ emitters by including inter-eruptive periods.

Given that our data set, by necessity, includes a number of spot measurements, the relative contribution of the most active volcanoes might continue to diminish as longer records are obtained at more volcanoes. As a first-order test, we compare the data set from direct measurements (many of which are spot measurements) with the $\mathrm{CO}_{2}$ flux estimated from global compilations of the most active volcanoes that represent longer time frames. We utilize the 2005-2015 OMI volcanic $\mathrm{SO}_{2}$ flux measurements ${ }^{75}$ and combine these with $\mathrm{CO}_{2} / \mathrm{SO}_{2}$ ratios from Aiuppa et al. ${ }^{73}$ and elsewhere where available to estimate $\mathrm{CO}_{2}$ emissions from these sources (Supplemental Table 8.1). At the time of writing, 49 of the 91 volcanoes in the OMI data $\mathrm{set}^{75}$ have their volcanic gas $\mathrm{CO}_{2} / \mathrm{SO}_{2}$ ratio signatures characterized (Supplemental Table 8.1), leaving a sizable gap in our knowledge. If only the $\mathrm{CO}_{2}$ emissions from these 49 volcanoes are summed, the OMI-based data result in a total $\mathrm{CO}_{2}$ emission of only $27 \mathrm{Tg} / \mathrm{yr}$, compared to the $44 \mathrm{Tg} / \mathrm{yr} \mathrm{CO}_{2}$ by direct measurements (Supplemental Table 8.1). Overall, a reasonable correlation exists between the two data 

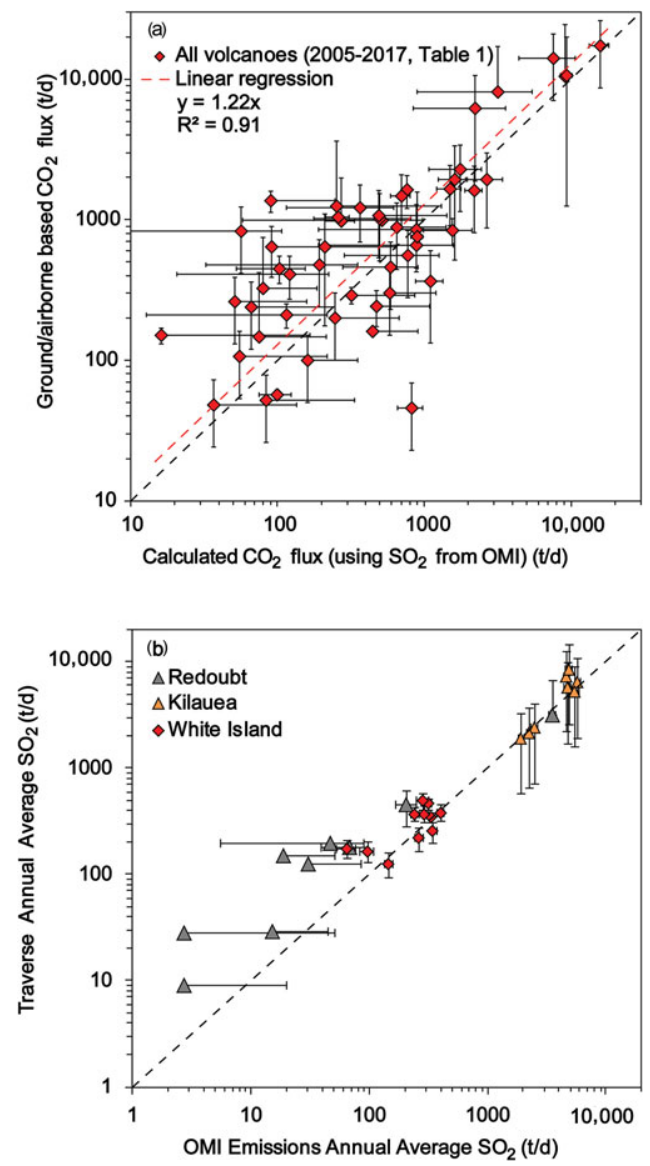

Figure 8.2 (a) Decadal average of $\mathrm{CO}_{2}$ emissions from direct measurements for the period 2005-2017 (as available; see Supplemental Table 8.1) compared to that calculated from decadal average $\mathrm{SO}_{2}$ emission from $\mathrm{OMI}$ and $\mathrm{C} / \mathrm{S}$ ratio estimates. (b) Annual average $\mathrm{SO}_{2}$ measurements from direct measurements for the years 2005-2015 when available (Redoubt, ${ }^{65,91,93}$ White Island, ${ }^{33,94,95}$ and Kilauea ${ }^{96}$ compared to annual OMI estimates ${ }^{75}$ ). Error bars show one standard deviation over the period of observations in both (a) and (b), and uncertainties in OMI-derived values are propagated. Note that annual variability is low at open-system volcanoes.

sets, with scatter about the 1:1 line (Figure 8.2a), but each data set is associated with significant variability over the decadal period. The variability in the decadal average $\mathrm{CO}_{2}$ flux is mirrored by the spread of the $\mathrm{SO}_{2}$ annual averages over a decadal period (Figure $8.2 \mathrm{~b}$ ), pointing to inherently large temporal variability in the emission rates from active volcanoes over multiyear periods (see also Section 8.6.1) and suggesting that the spread in $\mathrm{CO}_{2}$ data could be related to different observation periods. This lies in contrast to variability in $\mathrm{SO}_{2}$ emission on an annual basis from the open-vent volcanoes; where frequent measurements have been made, variability is low and data cluster around the 
1:1 line. This suggests that OMI-derived estimates of $\mathrm{CO}_{2}$ emissions are accurate when the $\mathrm{C} / \mathrm{S}$ ratios of volcanic gases are measured frequently. Future work should focus on a rigorous, systematic inter-comparison study between satellite and ground-based $\mathrm{SO}_{2}$ flux data sets and on capturing the temporal variability in volcanic gas chemistry.

Given the importance and potential further use of the long-term $\mathrm{OMI} \mathrm{SO}_{2}$ data sets ${ }^{75,77}$ for estimating global $\mathrm{CO}_{2}$ emission rates, it is important to note that many of the "passive" degassing measurements ${ }^{75}$ in fact represent eruptive periods. For instance, the OMI decadal data set omits eruptive emissions using a threshold $\mathrm{SO}_{2}$ amount, ${ }^{75}$ which excludes largescale explosive emissions, but here we show that the data set includes emissions from eruptive and inter-eruptive periods. If we consider passive degassing to be degassing in the absence of eruption, we can compare the GVP volcanic eruption database ${ }^{97}$ with the $\mathrm{OMI} \mathrm{SO}_{2}$ degassing data set. On an annual basis, 10 of the 91 volcanoes $(11 \%)$ reflect true passive degassing such that the volcanoes did not experience an eruption between 2005 and 2015. Furthermore, $24 \%$ of the volcanoes erupted at least once every year; and, in any given year, at least half of the volcanoes experienced an eruption during this decade (the minimum number was 45 volcanoes erupted in a given year). For comparison, on average of $83( \pm 1.6)$ volcanoes experienced a non-zero $\mathrm{SO}_{2}$ flux in a given year, suggesting that roughly half of the volcanoes might be considered to be passively degassing on an annual basis.

It is also important to note that the $\mathrm{OMI} \mathrm{SO}_{2}$ data set almost exclusively represents volcanoes with predominantly basaltic or basaltic-andesite compositions and is thus not globally representative of Earth's more silicic systems. Basaltic systems have been shown to have the shortest repose periods (averaging $<1$ year), whereas basaltic-andesite systems can show much longer periods of repose (averaging roughly 20 years), ${ }^{98}$ with the latter approaching the length of time that the volcanic gas community has been making $\mathrm{CO}_{2}$ emission rate measurements. Thus, we suggest that future work should also focus on analyzing time series data that span eruptive cycles at the more silicic of this set of dominantly mafic volcanoes to understand how emissions vary over multi-decadal time periods that include both periods of repose and open-vent degassing.

\subsection{2 $\mathrm{CO}_{2}$ Emissions during Explosive Eruptions}

Our present knowledge of $\mathrm{CO}_{2}$ emissions from large, explosive eruptions is limited owing to both proximal hazards and instrumental challenges in measuring volcanic gases during such events. Direct assessment of $\mathrm{CO}_{2}$ emission rates during explosive eruptions has been achieved on rare occasions, either from airborne plume measurements (e.g. during the 2009 Redoubt eruption, ${ }^{65}$ though here the most explosive events were not captured) or by coupling real-time FTIR spectroscopy of $\mathrm{CO}_{2} / \mathrm{SO}_{2}$ ratios in eruptive gases with the UVsensed $\mathrm{SO}_{2}$ flux (e.g. during the 2010 Eyjafjallajökull eruption ${ }^{99}$ ). In other cases, bulk $\mathrm{CO}_{2}$ emissions from explosive eruptions have been estimated by combining $\mathrm{CO}_{2} / \mathrm{SO}_{2}$ data from in situ measurements with satellite-based $\mathrm{SO}_{2}$ data or by modeling the pre-eruptive vaporphase composition. ${ }^{100-102}$ Such techniques yield, for instance, estimates of $\sim 10$ and $\sim 50 \mathrm{Mt}$ $\mathrm{CO}_{2}$ for the 1980 Mount St Helens and 1991 Pinatubo eruptions, respectively. ${ }^{103}$ These 
estimates imply $\mathrm{CO}_{2} / \mathrm{SO}_{2}$ mass ratios of $\sim 3-10$ in the eruptive emissions, although higher ratios cannot be excluded. ${ }^{100}$ Indeed, mass budgets for these and other explosive eruptions of silicic magmas strongly suggest pre-eruptive accumulation of a $\mathrm{CO}_{2}$-rich vapor phase. ${ }^{100,104}$ Gas accumulation in silicic magma reservoirs between eruptions can result from the second boiling of vapor-saturated crystallizing magma and/or volatile supply from basalt underplating. ${ }^{105}$ Magmatic vapor may migrate to the roof zones of reservoirs via gas transport through channelized flow in crystal-rich mush. ${ }^{106}$ Because of its low solubility, $\mathrm{CO}_{2}$ becomes preferentially enriched in the accumulating vapor phase. Therefore, high $\mathrm{CO}_{2} /$ $\mathrm{SO}_{2}$ ratios ${ }^{107}$ and high $\mathrm{CO}_{2}$ and $\mathrm{SO}_{2}$ fluxes ${ }^{108,109}$ can be expected during the initial phases of explosive eruptions that tap the gas-rich upper levels of magma reservoirs.

Measuring volcanic $\mathrm{CO}_{2}$ emissions during explosive eruptions will continue to be challenging regardless of whether one is using in situ or satellite techniques. In situ measurements of explosive eruption plumes are hampered by proximal volcanic hazards and high atmospheric ash loadings, ${ }^{101}$ and spaceborne $\mathrm{CO}_{2}$ measurements will also be hindered by volcanic ash. However, UAV (or drone) technology and improved satellite $\mathrm{SO}_{2}$ instruments (e.g. TROPOMI) hold great promise to improve measurements of explosive volcanic $\mathrm{CO}_{2}$ emissions in the coming decade.

\subsection{3 $\mathrm{CO}_{2}$ Emissions from Dormant Volcanoes}

It has been recognized for some time that volcanoes that are dormant (defined here as not erupting but likely to erupt again) emit significant amounts of $\mathrm{CO}_{2} \cdot{ }^{110,111}$ These volcanoes may support smaller $\mathrm{CO}_{2}$ plumes that may or may not contain $\mathrm{SO}_{2}$ derived from fumarolic emissions, or they may host large regions of diffuse degassing (Supplemental Table 8.3) related to silicic volcanism that have long repose times typical of caldera settings. Below we review each source separately.

\subsubsection{Small Volcanic Plumes: Fumarolic Contributions}

Volcanoes that produce small plumes, or $\mathrm{CO}_{2}$ plumes in the absence of significant $\mathrm{SO}_{2}$ emission, are more difficult to characterize for their $\mathrm{CO}_{2}$ emission rate than those that have strong $\mathrm{SO}_{2}$ plumes. Roughly $40 \%$ of the 102 direct $\mathrm{CO}_{2}$ flux measurements listed in Supplemental Table 8.1 are from volcanoes where the volcanic plume was not detected by $\mathrm{OMI}^{75}$ and thus fall in this category (we refer to these as "small plumes," although some do not have low $\mathrm{CO}_{2}$ emissions). The $\mathrm{CO}_{2}$ emissions associated with these volcanoes range from 13 to nearly $1500 \mathrm{t} / \mathrm{d}$, with an average of $300 \mathrm{t} / \mathrm{d}(1 \sigma= \pm 360)$ and a median of $147 \mathrm{t} / \mathrm{d}$, excluding the large emission from Oldoinyo Lengai (Tanzania). Some of the largest $\mathrm{CO}_{2}$ emissions are from active volcanoes that host crater lakes (e.g. Taal and Pinatubo, Philippines; Ruapehu, New Zealand; Supplemental Table 8.1) and from better-studied sections of arcs in the United States (Cascades and Alaska), Central and South America, and Indonesia (Supplemental Table 8.1). Where airborne methods and easy access have allowed for measurements, the data show that such emissions are common and are likely widespread in many arcs globally (Figure 8.3a). 


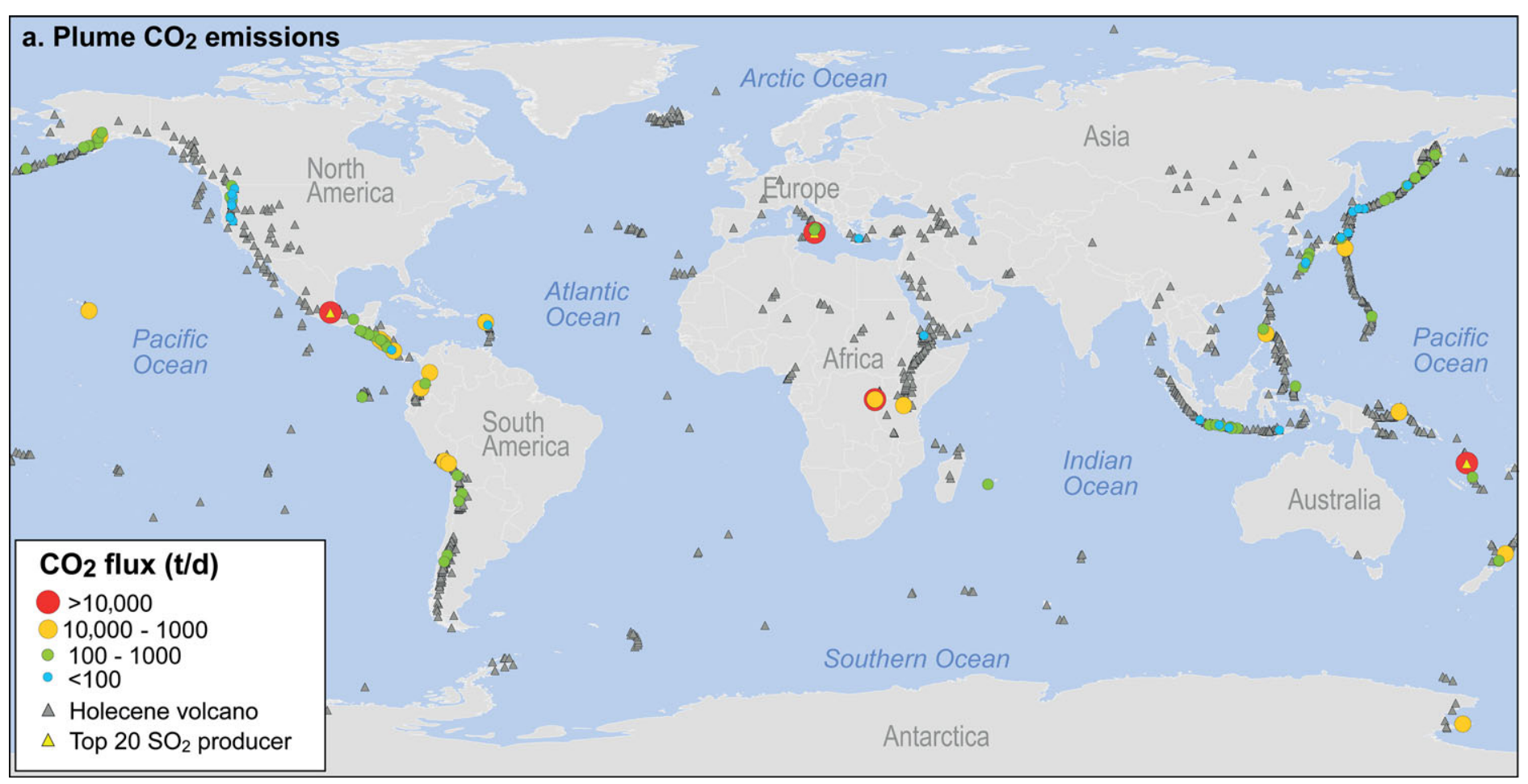

Figure 8.3 Measured $\mathrm{CO}_{2}$ emissions from (a) active volcanoes (plume emissions; Supplemental Table 8.1) and (b) diffuse degassing sources (Supplemental Table 8.2). All plume emissions are from Holocene volcanoes. Diffuse emissions are from volcanic sources with a broader period of activity; hydrothermal locations are often colocated with active volcanoes (i.e. Holocene volcanoes). Volcano locations from $\mathrm{Ref}$ 97, top $20 \mathrm{SO}_{2}$ producers from Ref. 75, and hydrothermal system locations from a modified version of the database from Ref. 113. 


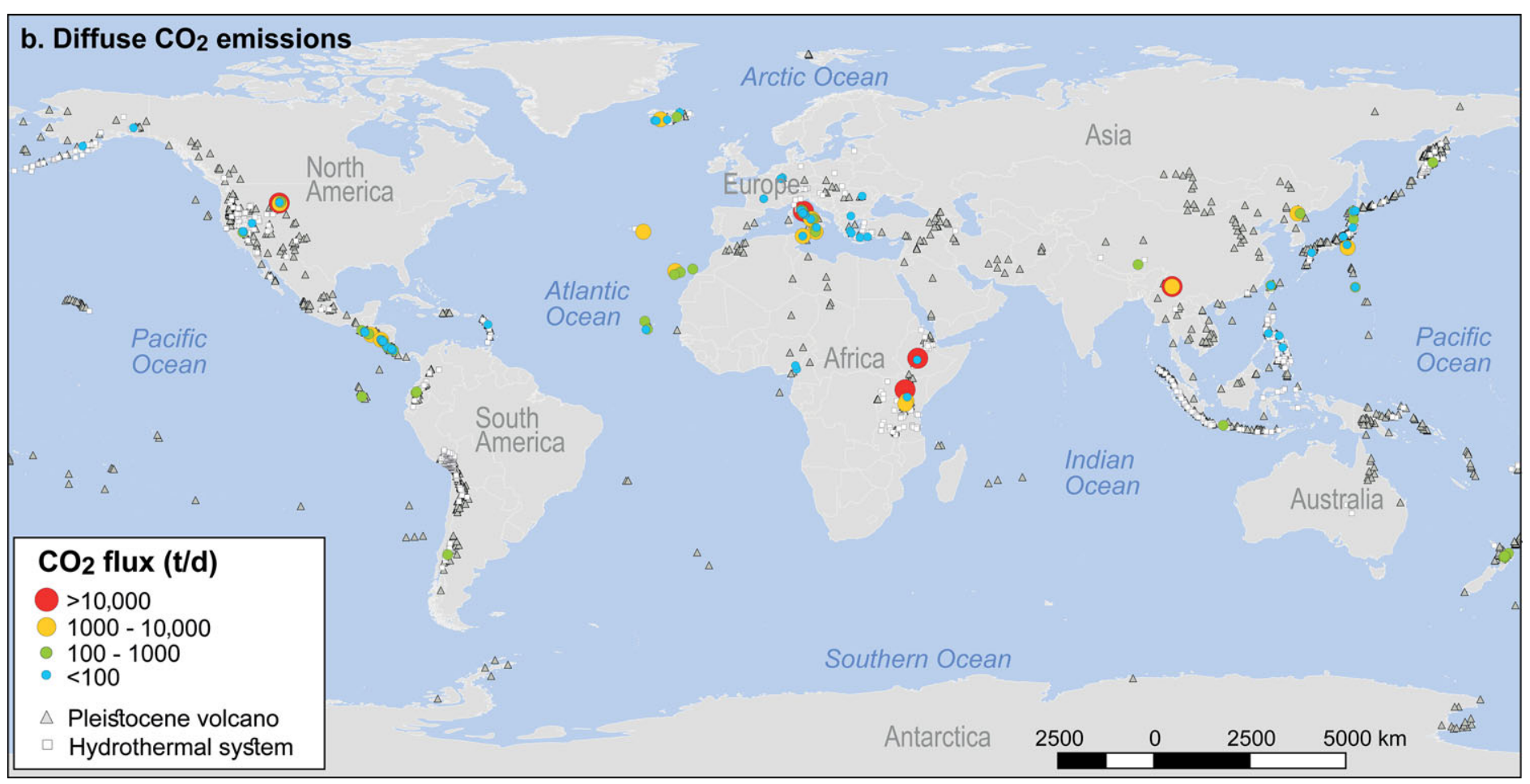

Figure 8.3 (cont.) 
If we simply sum the $\mathrm{CO}_{2}$ emissions from these "small" volcanic plumes, they amount to only $5 \mathrm{Tg} \mathrm{CO}_{2} / \mathrm{yr}$ of the $44 \mathrm{Tg} / \mathrm{year}$ in Supplemental Table 8.1, demonstrating the dominance of strongly emitting volcanoes in the data set. However, if we take the volcanoes that have erupted in the last 100 years $(n=407)$ minus the 83 volcanoes that are shown to be degassing each year (Section 8.4.1), resulting in 324 volcanoes globally, and assume that each outputs on average $300 \mathrm{t} / \mathrm{d}$, this equates to $35 \mathrm{Tg} \mathrm{CO}_{2} / \mathrm{yr}$. If we use the median (147 t/d) instead of the average, this results in $17 \mathrm{Tg} \mathrm{CO}_{2} / \mathrm{yr}$. This exercise suggests that the emissions from volcanoes with small plumes (or in the absence of $\mathrm{SO}_{2}$ emission) could potentially emit a similar order of magnitude of $\mathrm{CO}_{2}$ globally as volcanoes whose $\mathrm{SO}_{2}$ plumes were detected by satellite. This result, if robust, would potentially stand in contrast to recent regional studies in Japan ${ }^{57,112}$ that suggest that the global volatile budget is dominated by the high $\mathrm{SO}_{2}$-emitting volcanoes, although this study ${ }^{57}$ recognized that the data set lacked comprehensive measurements for the less active, diffusely degassing volcanoes. While challenging, more work is needed to verify the global contribution of $\mathrm{CO}_{2}$ emissions from volcanoes that do not emit satellite-detectable $\mathrm{SO}_{2}$.

\subsubsection{Diffuse Emission of $\mathrm{CO}_{2}$ : Hydrothermal Systems, Calderas, and Continental Rifts}

Our understanding of the magnitude of the diffuse $\mathrm{CO}_{2}$ flux from volcanic and magmatically active regions on Earth continues to evolve with each year of new measurements, and we now understand this to be a significant outgassing source. What we show here is that diffuse $\mathrm{CO}_{2}$ outgassing from calderas and dormant volcanic regions can rival outgassing from actively erupting volcanoes (Figures 8.3, 8.4, and 8.5). Quantification of such fluxes on global scales, however, remains a great challenge. Available flux data for diffuse gas emissions have been gathered, together with data from active volcanoes, into a database (the MaGa web database: www.magadb.net ${ }^{114}$ ). The data show that there are large regions where measurements have not yet been made (e.g. South America, Kamchatka, and Southeast Asia; Figure 8.3b). As new discoveries of large emission sources have been made in the last 10 years in areas with large magmatic intrusions and concentrations of hydrothermal systems (e.g. the East African Rift (EAR) and the Technong volcanic province, China), we expect that additional important areas will be located in the future.

If we compare the distribution of measured diffuse emissions of $\mathrm{CO}_{2}$ (Figure 8.5a and Supplemental Table 8.3) with plume emissions from active volcanoes (Supplemental Table 8.1), we find significant overlap and similarity in the emission rates, especially at higher rates. The diffuse emission data tend to be bimodal, with a larger population at low emission rates (Figure 8.5a), but the lack of measurements at low $\mathrm{CO}_{2}$ emissions for active volcanoes may simply reflect a sampling bias due to method limitations (e.g. fumarolic contributions and plumes below $\mathrm{SO}_{2}$ satellite detection limits). Volcanic systems that have diffuse emission rates between 100 and $500 \mathrm{t} / \mathrm{d}$ are most common, representing $30 \%$ of the data, with an additional $20 \%$ falling between 500 and $5000 \mathrm{t} / \mathrm{d}$. The highest $\mathrm{CO}_{2}$ emission rates are for large magmatic systems (e.g. Yellowstone in the United States, the Tengchong Volcanic Field in China, the Tuscan Roman degassing structure (TRDS) and Campanian degassing structure (CDS), and the EAR system; Supplemental Table 8.3). Although 

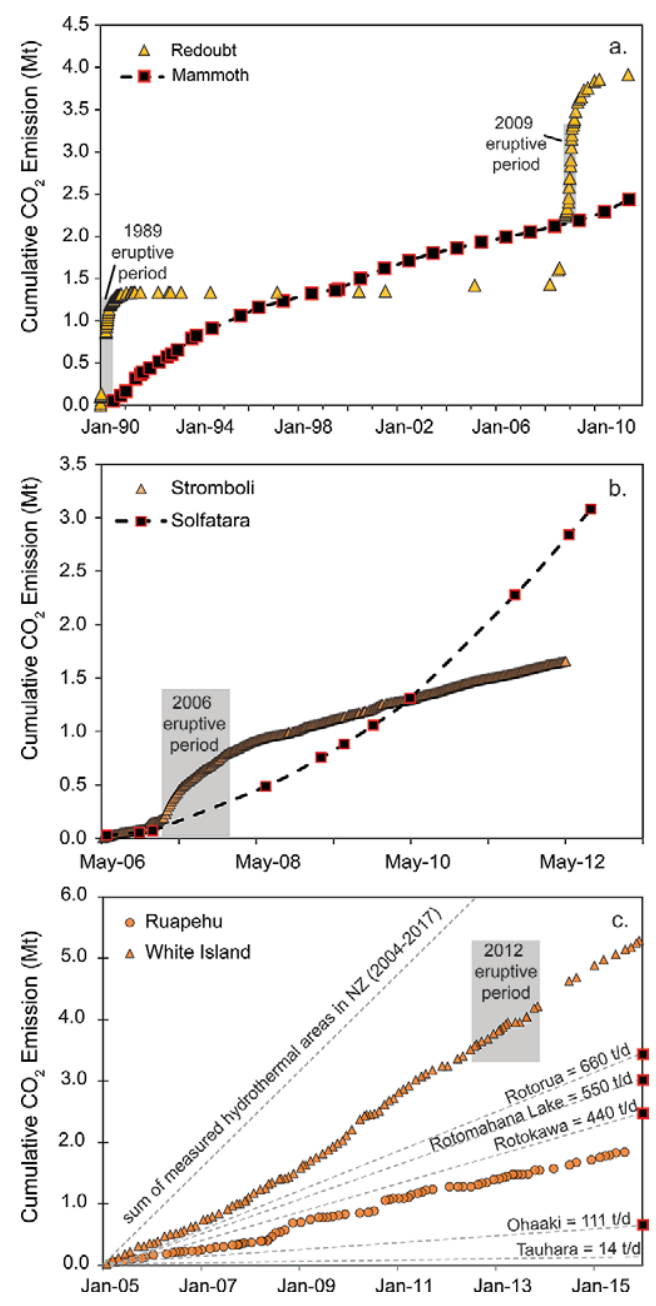

Figure 8.4 Cumulative $\mathrm{CO}_{2}$ emissions for some of the best-studied volcanoes in the world showing the comparison of vent emissions (triangles) to diffuse emissions (squares and dotted lines). (a) Emissions from Redoubt volcano and those of Mammoth mountain are roughly equal over 20-year time frames. Redoubt data from Refs. 65, 91, 93, and 115 and Mammoth data from Ref. 116. (b) Solfatara data from Ref. 117, Stromboli data from Ref. 118. (c) White Island data from Refs. 33 and 119, Ruapehu data from Refs. 32, 94, and 95, Taupo Volcanic Zone diffuse degassing data from Refs. $120-123$.

estimates for these systems have large uncertainties, high emission rates are consistent with high heat fluxes and voluminous magmatism. As run-up time, or period of unrest prior to an eruption, is positively correlated with the repose period between eruptions, ${ }^{98}$ it should not be surprising that some of the largest and longest-lived volcanic systems (e.g. silicic calderas systems) can produce some of the largest $\mathrm{CO}_{2}$ emissions globally (e.g. Yellowstone, Campi Flegrei, and Rotorua; Supplemental Table 8.3). 

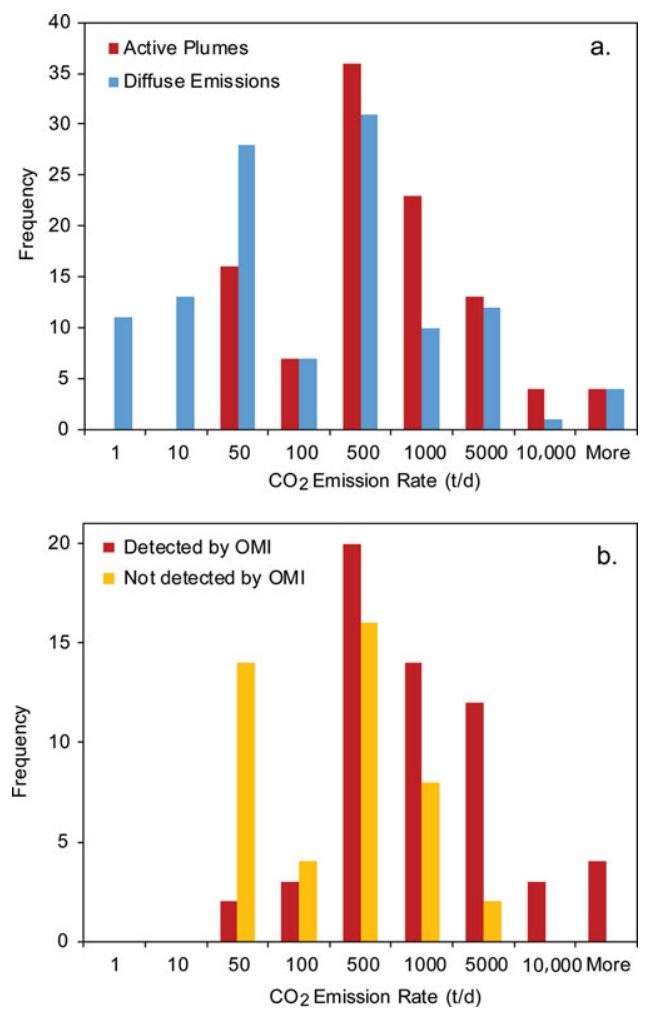

Figure 8.5 Distribution of $\mathrm{CO}_{2}$ emission rate data for (a) active volcanic plumes (Supplemental Table 8.1) and diffuse emissions (Supplemental Table 8.2) and (b) the active volcano plumes that were detected for passive degassing by $\mathrm{OMI}^{75}$ and those volcanoes that were not.

Unrest in caldera systems is common, ${ }^{124,125}$ and thus using unrest catalogs may allow us to understand and constrain this likely significant $\mathrm{CO}_{2}$ source better. Globally, there are 446 caldera systems, of which 225 have erupted in the Quaternary and 97 in the Holocene. ${ }^{124,125}$ At caldera systems, unrest is understood to be driven by the influx of mafic, volatile-rich magma to the base of relatively shallow reservoirs containing vapor-saturated magma (Figure 8.1). In a recent study of the best-monitored caldera systems in the world, such episodes of magma intrusion were found to be the fundamental driver of unrest, ${ }^{124}$ and $71 \%$ exhibited changes in degassing with unrest. At mafic calderas, unrest often proceeded to eruption, whereas felsic systems were thought to have a higher capacity to accommodate magmatic intrusions without leading to an eruption. ${ }^{124}$ The hydrothermal systems and gas reservoirs that often lie above such intrusions act as buffers, such that changes in gas emission at the surface are often delayed by some time (sometimes years) from the time when fresh magma is intruded. ${ }^{116,124,126}$ However, the time-averaged release of $\mathrm{CO}_{2}$ from these systems is roughly similar to that of many active volcanoes (Figure 8.4). The main difference may then be the contrast in available pathways for gas release: active 
(and often mafic) volcanoes maintain open conduits with high permeability (Supplemental Table 8.1) and dormant (often silicic) volcanoes and caldera systems release gas along faults and fracture networks with lower permeability than open conduits, resulting in regions of diffuse emissions (Supplemental Table 8.3).

Here, for the first time, we show that net release of $\mathrm{CO}_{2}$ over time (decades) from areas of diffuse degassing for several well-studied systems that have not erupted in recent history (e.g. Mammoth Mountain, USA; Solfatara, Italy; Rotorua, New Zealand) can rival that of active volcanoes that have experienced an eruption recently (Etna and Stromboli, Italy; Redoubt, USA; White Island, New Zealand). The active volcanoes are all on the list of top $\mathrm{SO}_{2}$-producing volcanoes in the world. ${ }^{75}$ For example, the $\mathrm{CO}_{2}$ emission from Mammoth Mountain (last eruption $70 \mathrm{ka}^{116}$ ) over $\sim 20$-year timescales is similar to that of Redoubt Volcano (Figure 8.4a). In this case, the long-term average emission is fundamentally controlled by the period of observation (e.g. note that the 2005-2015 average emission is an order of magnitude higher in Supplemental Table 8.1 than the average over two decades portrayed in Figure 8.4a). Another example is the long-term cumulative emission from Solfatara in Campi Flegrei, Italy, which exceeds that of Stromboli Volcano (Figure 8.4b). And finally, the emission from White Island is dwarfed by the sum of the cumulative $\mathrm{CO}_{2}$ emissions from dormant volcanoes in New Zealand (Figure 8.4c).

It is not known how many hydrothermal systems exist on Earth, but the majority are associated with areas of either present or past volcanism. Our current summation of the extent of diffuse degassing from dormant volcanoes is $\sim 64 \mathrm{Tg} / \mathrm{yr}$ (Supplemental Table 8.3), which is similar to that published previously, ${ }^{15}$ but our estimate does not include largescale extrapolated values for Indonesia-Philippines and the Subaerial Pacific Rim. ${ }^{127}$ Our data highlight the importance of several large regions of localized hydrothermal activity. While work in several areas has already begun and has yielded valuable initial data (Yellowstone, USA; ${ }^{128,129}$ Campi Flegrei, Italy; ${ }^{117,130}$ the TRDS and CDS, central Italy; ${ }^{131,132}$ the EAR; ${ }^{133,134}$ and the Taupo Volcanic Zone (TVZ), New Zealand ${ }^{120,122,123}$ ), we expect several other areas will also be globally important for their $\mathrm{CO}_{2}$ emissions. Guidance for where these areas might be located can be gleaned from global assessments of geothermal energy reserve. In a 2016 review by the World Energy Council, ${ }^{135}$ the five nations with the highest potential geothermal generating capacity were the USA, the Philippines, Indonesia, Mexico, and New Zealand. Several of these countries have had very few $\mathrm{CO}_{2}$ surveys to date. On the other hand, countries such as Italy and Japan (ranked 6th and 10th, respectively, on the list of top nations) have had considerably more studies.

Here, we attempt to estimate the number of hydrothermal areas worldwide by building on a list of geothermal systems capable of power production, ${ }^{113}$ adding in hydrothermal areas located in Alaska, Kamchatka, and Peru. This results in $\sim 670$ hydrothermal regions worldwide (Figure 8.2). The average of all diffuse emissions from localities that have not experienced eruptive activity since 2000 is $340 \pm 628 \mathrm{t} / \mathrm{d}$, demonstrating a positive skew in the population. We omitted hydrothermal areas on volcanoes with eruptions since 2000 because we did not want to include anomalous data due to recent volcanism. This average also does not include large-scale magmatic emission estimates (Supplemental 
Table 8.4) because these areas are also anomalous on a global scale and are not representative of individual hydrothermal regions. While admittedly simplistic, applying this average to the 670 hydrothermal regions worldwide would result in $83 \mathrm{Tg} \mathrm{CO}$ /year, or an additional $30 \%$ over the current summation of the diffuse data. We consider it likely that this estimate is conservative given: (1) that our data only represent 135 of 670 localities; (2) these data largely do not include groundwater contributions that may be similar in magnitude to diffuse emissions (see Ref. 57 and references therein); and (3) the discovery of other large systems globally (such as Yellowstone) could add significantly to the budget (currently, large magmatic provinces sum to $75 \mathrm{Tg} \mathrm{CO}_{2} / \mathrm{yr}$; Supplemental Tables 8.3 and 8.4).

The TVZ is a region that deserves extra attention given its unique tectonic setting and high heat flow and because arc-scale extrapolations based on studies from the TVZ ${ }^{127}$ continue to be used for global compilations and comparisons of $\mathrm{CO}_{2} \cdot{ }^{15,134}$ The TVZ is an intra-arc rift zone that hosts over 20 separate hydrothermal regions with heat flux greater than $20 \mathrm{MW},{ }^{136}$ and many of these regions are exploited for geothermal energy. Previous estimates of the $\mathrm{CO}_{2}$ output of the TVZ as a whole have been extrapolated based on the heat flux and the $\mathrm{CO}_{2}$ content of upwelling fluids. However, diffuse $\mathrm{CO}_{2}$ flux at the surface ${ }^{120,122,123}$ for many of these systems greatly exceeds previous $\mathrm{CO}_{2}$ emission estimates for these areas, without including fumarolic contributions. As an example, the emission rate estimated for the Rotorua hydrothermal system alone (estimated at $\sim 1000 \mathrm{t} / \mathrm{d}$, including sub-lacustrine degassing; ${ }^{123}$ Supplemental Table 8.3$)$ is nearly equal to that previously estimated for the whole TVZ $\left(\sim 1200 \mathrm{t} / \mathrm{d}^{127}\right)$. To date, 7 of the 18 hydrothermal systems have been measured for $\mathrm{CO}_{2}$; together, they equal a total of $\sim 2000 \mathrm{t} / \mathrm{d}$. Further investigation is required to determine why the previous estimates for the TVZ hydrothermal systems were low, but likely this results from underestimating the $\mathrm{CO}_{2}$ content of the deep hydrothermal fluids or degassing from gas reservoirs at depth. ${ }^{117,137}$ In any case, arcscale estimates for other regions on Earth should not be based on TVZ data, ${ }^{127}$ and continued effort should be placed on measuring the total diffuse $\mathrm{CO}_{2}$ output from typical arcs and high-heat-flow regions around the world.

The EAR, also deserving of extra attention due to its high global output, is a series of rift valleys that extend $4000 \mathrm{~km}$ from the Afar region in the north to Beira in Mozambique in the south. ${ }^{138}$ The system is split into an eastern branch, which hosts the Main Ethiopian Rift (MER) in the north and the Kenyan rift in the south. In these two sectors alone, there exist 36 volcanoes and 28 hydrothermal areas. The western branch of the EAR is characterized by a lack of recent volcanism relative to the eastern branch, but still hosts a number of geothermal prospects as well as Nyiragongo, a major emitter of $\mathrm{CO}_{2}$. Several recent studies attempted to estimate the diffuse $\mathrm{CO}_{2}$ flux from the EAR. One study focused on the centers of volcanic activity in the MER and extrapolated that to between 3.9 and $33 \mathrm{Tg} \mathrm{CO} / \mathrm{yr}$ for the EAR. ${ }^{134} \mathrm{~A}$ second study focused on tectonic degassing away from active volcanic centers and estimated 38-104 $\mathrm{Tg} \mathrm{CO} / \mathrm{yr}$ for the EAR, not including focused degassing through the active centers. ${ }^{133}$ For our estimate, we use the midpoint of the range presented by Hunt et al. ${ }^{134}$ because our aim is to estimate volcanic degassing; this value is one-third of the 
total $\mathrm{CO}_{2}$ emissions from all diffuse sources in our compilation (Supplemental Table 8.3). While the estimates of EAR fault-related degassing ${ }^{133}$ are not volcanic per se, isotopic evidence suggests there exists a significant flux of mantle-derived $\mathrm{CO}_{2}$ to the atmosphere through these structures, and using these data would increase significantly the global contribution of the EAR. We caution that both studies found relatively few measurements of modest to high $\mathrm{CO}_{2}$ flux in faulted or hydrothermal areas and that these results were then extrapolated over extensive regions. Significant uncertainty is associated with such largescale extrapolations, particularly when diffuse $\mathrm{CO}_{2}$ flux can vary on meter scales. However, it is clear the EAR is a very important region for global $\mathrm{CO}_{2}$ emissions, and more work is needed to quantify the flux of $\mathrm{CO}_{2}$ from this and other areas of continental rifting/extension that support volcanism and hydrothermal activity, such as the Rio Grande Rift in New Mexico and the Rhine Graben and the Eger Rift in Central Europe. Such areas could potentially add $30-40 \mathrm{Tg} \mathrm{CO}_{2} / \mathrm{yr}$ (or $8-11 \mathrm{Tg} \mathrm{C} / \mathrm{yr}$ ) to global budgets, and potentially be on the same order as global arc fluxes.

\subsection{The Next Iteration of Global Volcanic $\mathrm{CO}_{2}$ Emissions}

As our understanding of the distribution and magnitude of volcanic and magmatic $\mathrm{CO}_{2}$ degassing evolves, so will our ability to estimate accurately the present-day global $\mathrm{CO}_{2}$ emission from these areas. As a culmination of the DECADE program, scientists came together in May 2018 to constrain better the total global $\mathrm{CO}_{2}$ flux from volcanic regions, as well as corresponding uncertainties. Here, we follow simple methods based on the extrapolation of measured data to determine a global subaerial volcanic $\mathrm{CO}_{2}$ budget (Supplemen-

tal Table 8.4). Our methods are similar - and thus comparable - to previous studies, ${ }^{15,57}$ but future work should focus on a rigorous statistical analysis of the data and more complex extrapolation procedures that lie beyond the scope of this chapter.

We break down the subaerial volcanic budget into three main categories: (1) passive degassing for active volcanoes, dividing these into those that have been detected by OMI and those that have not; (2) diffuse emissions from both active and dormant volcanoes, with groundwater contributions (not estimated) and large degassing provinces as separate categories; and (3) eruptive emissions. We first calculate the average of the measurements of $\mathrm{CO}_{2}$ flux from the volcanoes that have been measured using ground-based or airborne techniques (i.e. measured directly) that were detected by $\mathrm{OMI}^{75}$ (58 of 91 volcanoes in Supplemental Table 8.1) and apply the average emission from these volcanoes (1730 \pm $440 \mathrm{t} / \mathrm{d}$, mean and standard error) to the 83 volcanoes (Section 8.4.1) that were degassing and detected by OMI globally on an annual basis between 2005 and 2015, yielding $52 \pm$ $13 \mathrm{Tg} \mathrm{CO}_{2} / \mathrm{yr}$ (Supplemental Table 8.4) for this set of volcanoes. Multiplying the average of the remaining 33 volcanoes from Supplemental Table 8.1 (i.e. those that do not emit $\mathrm{SO}_{2}$ in large enough quantities to be detected by $\mathrm{OMI}-$ the average $\mathrm{CO}_{2}$ output of these volcanoes is $300 \pm 68 \mathrm{t} / \mathrm{d}$; Supplemental Table 8.4) to 324 volcanoes results in $35 \pm 8 \mathrm{Tg}$ $\mathrm{CO}_{2} / \mathrm{yr}$. The sum of these results in $88 \pm 21$ for passive degassing from active volcanoes (Supplemental Table 8.4). How the value of 324 volcanoes was determined is discussed in 
Section 8.4.3. The uncertainty in this number is difficult to quantify without global arcwide assessments of the numbers of expected degassing volcanoes that have not been detected by OMI. To put this number in context, there are 169 active volcanoes in the United States, and $81(47 \%)$ have notable degassing as determined through visual surveys. ${ }^{139}$ Of these, $28(17 \%)$ are thought to have plumes large enough for airborne measurements, but only 8 (4\%) were detected by OMI ${ }^{75}$ Thus, $90 \%$ of the US volcanoes that emit $\mathrm{CO}_{2}$ and $71 \%$ of the US volcanoes that have plumes large enough for airborne surveying were not detected for passive degassing of $\mathrm{SO}_{2}$ by OMI. Similarly, of the 19 persistently degassing volcanoes in Japan ${ }^{112}$ during the period of OMI measurements, only 7 were detected by $\mathrm{OMI}^{75}$ (i.e. $63 \%$ were not detected by OMI). If this relationship were to hold globally (i.e. that $63-71 \%$ of volcanoes with significant $\mathrm{CO}_{2}$ emissions are not detected by OMI), this would suggest that 245-313 volcanoes with notable plume emissions worldwide remain undetected by OMI, which is similar to the value we used. We suggest that completing a global assessment of which volcanoes are degassing, and the nature of that degassing, based on visual assessment and documented activity in the GVP database would lead to a much more accurate estimate of the number of degassing volcanoes globally than the methods used here. However, it must be considered that additional invisible or nearly invisible emissions of $\mathrm{CO}_{2}$ may also exist. ${ }^{140-142}$

As discussed above, the $\mathrm{CO}_{2}$ contribution from explosive eruptions is poorly constrained. Here, we estimate eruptive emissions of $\mathrm{CO}_{2}$ (Supplemental Table 8.2) by combining recent decadal-scale (2005-2018) $\mathrm{SO}_{2}$ fluxes derived from satellite measurements of eruptions ${ }^{143}$ with the most representative $\mathrm{CO}_{2} / \mathrm{SO}_{2}$ ratios measured at corresponding volcanoes, and separate these data into explosive and effusive events (Supplemental Table 8.2). In previous estimates, $\mathrm{CO}_{2} / \mathrm{SO}_{2}$ ratios were assumed to have uniformly high values of 10 and 7 in the pre-eruptive vapors of silicic and basaltic magmas, respectively. ${ }^{57}$ Such an assumption is reasonable for initial phases, but is not necessarily valid for the whole eruption length. The figure we obtain by using measured ratios ( $0.6 \mathrm{Tg} / \mathrm{yr}$; Supplemental Table 8.2$)$ is much lower than previously estimated based on theoretical ratios $\left(7 \mathrm{Tg} / \mathrm{yr}^{57}\right)$. We anticipate that our value is likely underestimated and that the true answer may lie between these two values. Regardless, the estimates show that explosive emissions are minimal compared to the passive degassing estimates. $\mathrm{CO}_{2}$ emissions from effusive eruptions in the same period (Supplemental Table 8.2) are inferred by subtracting explosive $\mathrm{CO}_{2}$ emissions from the total $\mathrm{CO}_{2}$ load from all eruptions. In this case, the calculated contribution is similar to previous estimates ( 1.3 compared to $1 \mathrm{Tg} / \mathrm{yr} \mathrm{CO}$ for effusive eruptions ${ }^{57}$ ), and again the contribution is a small fraction of the total subaerial budget.

Our calculations suggest that diffuse degassing of $\mathrm{CO}_{2}$ from volcanoes is only slightly lower than that from active volcanic vent emissions, with diffuse emissions estimated at $83 \pm 15 \mathrm{Tg} / \mathrm{yr}$. However, combined contribution of $170 \mathrm{Tg} / \mathrm{yr} \mathrm{CO}_{2}$ from diffuse degassing from all volcanic-hydrothermal systems, including groundwater contributions and degassing related to large regions of intrusive magmatic activity is higher (Supplemental Table 8.4). This value is likely an underestimate given that fumarolic contributions (focused venting/small fumaroles) in regions of diffuse degassing are often not quantified as part of the estimation of degassing across such regions, and because groundwater contributions 
are largely unquantified. Furthermore, we anticipate the discovery of additional large emission sources as many of the countries with the highest potential for geothermal power generation have few measurements.

In total, we conservatively estimate global subaerial volcanic $\mathrm{CO}_{2}$ emissions to lie between 220 and $300 \mathrm{Tg} \mathrm{CO} / \mathrm{yr}$, and between 280 and $360 \mathrm{Tg} \mathrm{CO}_{2} / \mathrm{yr}$ including the contribution of MOR (Supplemental Table 8.4), based on currently known sources. Our estimates are lower than those published by Burton et al., ${ }^{15}$ but higher than previous estimates for global subaerial sources. ${ }^{111,144}$

\subsection{Temporal Variability of Volcanic Degassing}

\subsubsection{Comparison of the Temporal Variability of $\mathrm{CO}_{2}$ Emission from Active and Less Active Volcanoes}

Most of what we now know about the temporal evolution of $\mathrm{CO}_{2}$ emissions from volcanoes has been learned in the last two decades. Advances in instrumental techniques now permit continuous, real-time monitoring. ${ }^{51,56,145}$ The trends emerging from these data show that emissions vary dramatically with volcanic setting (Figure 8.1) and that timescales of observation are important for understanding the relative contributions from different systems. Active volcanoes with open-vent degassing such as Stromboli and Mount Etna (Italy) show orders of magnitude variability over very short time frames (Figure 8.6) correlating with magma supply and eruptive activity. ${ }^{53,54,146}$ In such active, often mafic systems, volatiles reach the atmosphere via magma convection, permeable gas flow, or bubble rise through low-viscosity melts. ${ }^{18,147}$ Despite short-term variability, the long-term average output at these volcanoes stays relatively constant over multiyear periods (Figure 8.4). In some cases, paroxysmal-type activity will increase emissions for over a year before returning to the long-term average (see Stromboli, 2006; Figures 8.4b and 8.6). Minor eruptive activity, on the other hand, can be difficult to discern in long-term

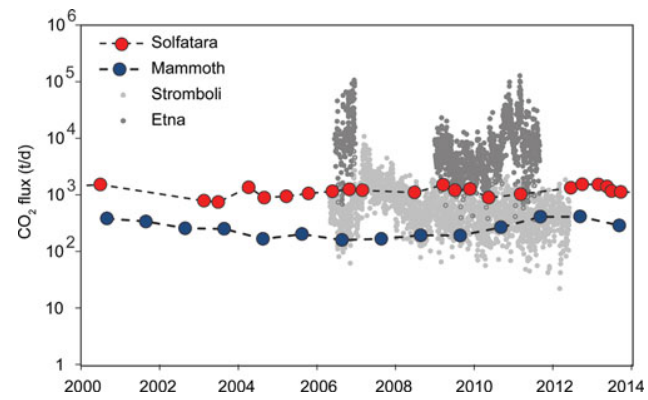

Figure 8.6 Temporal variability of $\mathrm{CO}_{2}$ emissions from some of the best-studied volcanoes in the world. Emissions from open-vent volcanoes vary dramatically in time, whereas diffuse emissions are buffered and show less variability. Solfatara data from Ref. 117, Mammoth data from Ref. 116, Stromboli data from Ref. 118, and Etna data from Ref. 148. 
trends. For instance, White Island and Ruapehu (New Zealand) demonstrate steady emissions over decadal periods during which eruptive activity is barely detectable (Figure 8.4c).

Closed-system volcanoes, or volcanoes that oscillate between closed- and open-vent degassing, can show dramatic variability in emissions over periods of years related to magma intrusion and variations in conduit permeability. Increases in $\mathrm{CO}_{2}$ emission rates are typically associated with eruptive activity (Redoubt; Figure 8.4a) and sometimes when intrusions occur without eruption. ${ }^{92}$ Periods of unrest can last months to years and are often accompanied by increases in emissions that then decrease exponentially following eruptive activity. Such behavior has been better documented for $\mathrm{SO}_{2}$ emissions, ${ }^{89,149}$ but is mirrored by $\mathrm{CO}_{2}$ emissions where measured (e.g. Redoubt in 1989 and $2009 ;{ }^{65}$ Figure $8.4 \mathrm{a}$ ).

Over an entire arc, the dominant volcanic $\mathrm{CO}_{2}$ producers may vary over decadal timescales, with some volcanoes becoming more or less active. A recent compilation of data for the Central American Arc estimated an arc-scale $\mathrm{CO}_{2}$ output one order of magnitude higher $\left(22,500 \pm 4900 \mathrm{t} / \mathrm{d}^{56}\right)$ than previous estimates, owing to the reactivation of Turrialba Volcano, as well as an increase in $\mathrm{CO}_{2}$ flux from Momotombo and Masaya volcanoes over the previous decade. Other arc segments have had similar changes to the overall degassing budget due to the reactivation of particular volcanoes (e.g. Miyakajima in Japan ${ }^{112}$ ).

Finally, large-caldera systems are thought to be underlain by silicic magma bodies, and in turn underplated by mafic magma. ${ }^{109}$ The $\mathrm{CO}_{2}$ emissions from such volcanoes, often modulated by large hydrothermal systems, show much less variability over annual or even decadal scales than emissions from active volcanoes (Figures 8.4 and 8.6). Where longterm measurements are available, small variations in the $\mathrm{CO}_{2}$ output in these systems often follow a geophysical manifestation of magma movement at depth ${ }^{116,150}$ whereby the transport of the gas to the surface is buffered by the overlying crust.

\subsubsection{Using the Temporal Variability of $\mathrm{CO}_{2} / \mathrm{SO}_{2}$ in Volcanic Gas for Eruption Forecasting}

It has been shown that the relative proportions of $\mathrm{C}$ and $\mathrm{S}$ change prior to and during eruptive activity. ${ }^{151,152}$ Owing to the low solubility of $\mathrm{CO}_{2}$ in silicate melts, ${ }^{153}$ the magmatic vapor phase typically has a high molar $\mathrm{C} / \mathrm{S}$ ratio at depths of $>\sim 5 \mathrm{~km}$ in the crust, ${ }^{102}$ and then $\mathrm{C} / \mathrm{S}$ decreases with magma ascent as more $\mathrm{S}$ exsolves from the magma. ${ }^{141,146}$ With more frequent monitoring of pre-eruptive volcanic gas using MultiGAS, we now know that an elevated $\mathrm{C} / \mathrm{S}$ in gas emissions is common prior to the onset of eruptions. ${ }^{51,55,154}$ In Figure 8.7a, we show variability of C/S over various timescales for 12 episodes at 7 volcanoes. One can observe that $\mathrm{C} / \mathrm{S}$ ratios increased to between 15 and 43 in the months to hours preceding eruption at five well-monitored basaltic volcanoes, whereas the long-term $\mathrm{C} / \mathrm{S}$ signature of shallow degassing at these volcanoes typically lies between 2 and 7 (Figure 8.7a to j). Such trends are often interpreted as the migration of deeply sourced gas bubbles prior to magma ascent. ${ }^{53,155}$ 


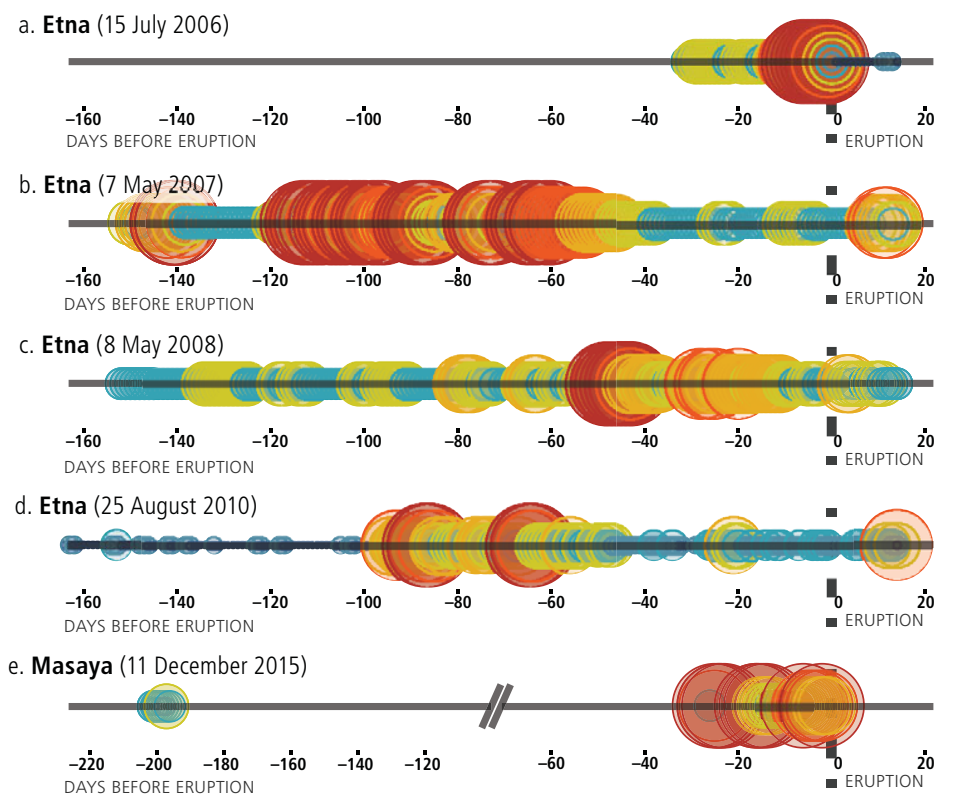

f. Stromboli (15 March 2007)

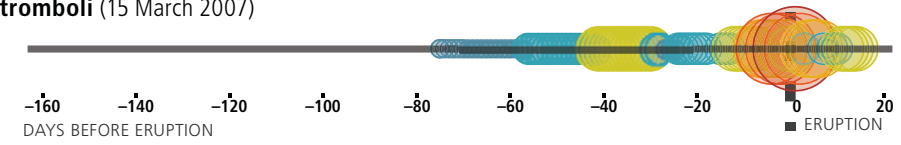

g. Stromboli (15 December 2006)

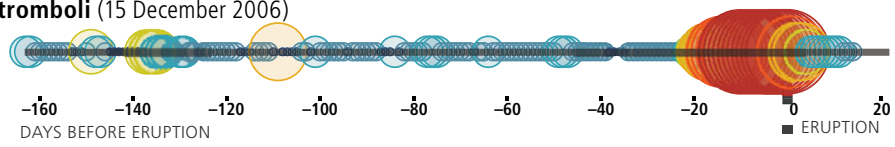

h. Turrialba (29 October 2014)

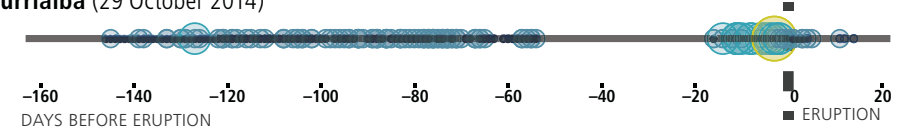

i. Turrialba (4 May 2015)

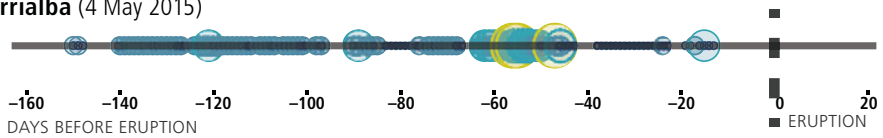

j. Villarica (3 March 2015)

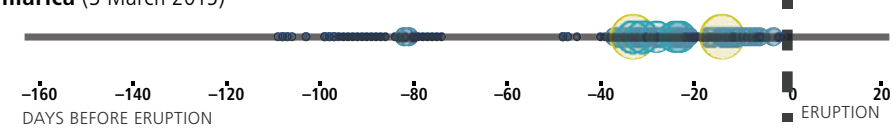

k. Kilauea (19 March 2008)

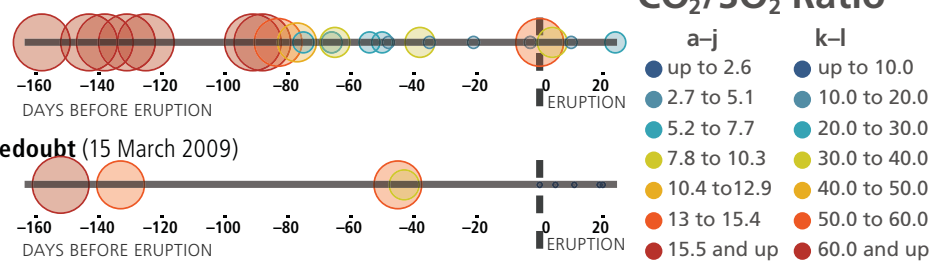

Figure 8.7 (a to j) Trends in C/S ratio observed at basaltic volcanoes monitored with MultiGAS instruments, with elevated $\mathrm{C} / \mathrm{S}$ documented in the months to hours prior to eruption. (k and $\mathrm{l})$ 
A second set of $\mathrm{C} / \mathrm{S}$ ratio observations has been made over somewhat longer timescales and is related to degassing of deep-seated magmas prior to ascent (Figures $8.7 \mathrm{k}$ and 1). Months- to years-long trends in $\mathrm{C} / \mathrm{S}$ were observed at both Redoubt ${ }^{141}$ and Kilauea ${ }^{140}$ volcanoes prior to eruption (Figure $8.7 \mathrm{~b}$ ). In both cases, the $\mathrm{C} / \mathrm{S}$ ratio was very high compared to the data observed at the other volcanoes, reaching values between 80 and 200, and both were associated with no visible plume (Figure 8.8). Documentation of this type of degassing is rare, but the occurrence is likely not rare. In the case of Redoubt, the pre-eruptive degassing of $\mathrm{CO}_{2}$ only amounted to roughly $15 \%$ of the total budget, ${ }^{65}$ but for Kilauea nearly $30 \mathrm{Mt}$ of gas escaped prior to eruption. Similar patterns of pre-eruptive gas release might be inferred, for instance, from the Holuhraun/

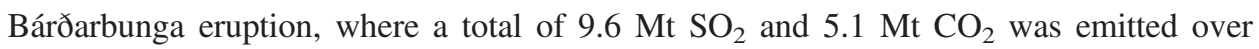
the course of the eruption. ${ }^{157}$ The low bulk $\mathrm{C} / \mathrm{S}$ ratio (0.7) compared to most hightemperature volcanic gases ${ }^{73}$ might imply that substantial amounts of $\mathrm{CO}_{2}$ degassed before monitoring began. In fact, a new study discovered significant degassing from glacially covered Katla volcano $\left(\sim 37 \mathrm{kt} / \mathrm{d} \mathrm{CO}_{2}\right)$ in the absence of a visible plume, unusual geophysical unrest, or $\mathrm{S}$ gas emission. ${ }^{142}$ These studies highlight a gap in our ability to detect $\mathrm{CO}_{2}$ degassing from volcanoes without dedicated airborne surveys downwind of potentially degassing volcanoes.

\subsection{Sources of Carbon Outgassed from Volcanoes}

Carbon outgassed at subduction zone volcanoes is sourced from the mantle, the subducted slab, and the overlying lithosphere (including the crust), ${ }^{158-162}$ whereas $\mathrm{CO}_{2}$ released from MORs and hot spots is dominated by mantle carbon. ${ }^{144,161}$ The carbon isotopic composition $\left(\delta^{13} \mathrm{C}\right)$ of the depleted MOR mantle (DMM) is $-5 \pm 1^{163,164}$ and that of plumes is documented as $-3.1 \pm 1.9$ (high-temperature fluids from Iceland ${ }^{165}$ ) and $-3.4 \%$ (Kilauea summit gas ${ }^{166}$ ), whereas the subcontinental lithospheric mantle likely contains carbon of composition between $-3.5 \%{ }^{133,167}$ and $-6 \%$ o. ${ }^{168}$ Research on $\mathrm{CO}_{2}$ sources in subductionzone volcanic gases has emphasized the role of carbon release from subducted sediments and carbonates and has shown that the type of material subducted imprints a carbon isotopic and $\mathrm{C} /{ }^{3} \mathrm{He}$ signature on the discharging gases. This approach, combined with $\mathrm{CO}_{2}$ fluxes from volcanoes, led to the development of volatile budgets in subduction zones and implies that more carbon is subducted than what is currently released by volcanoes, leading to the transfer of carbon into the deeper mantle and beyond the zones of arc magma generation. $^{70,79,169,170}$ Accumulation of subducted carbon below the arc crust or

Figure 8.7 (cont.) Observations of elevated high C/S ratios in the years prior to eruption. Decreasing trends in $\mathrm{C} / \mathrm{S}$ ratios were observed in the last 100 days prior to eruption. Both the symbol size and color scale with $\mathrm{C} / \mathrm{S}$ ratio, with larger and warmer symbols relating to higher C/S ratios. Data from Refs. 118 , $140,141,148,155$, and 156. At Masaya, the volcano (e) did not erupt, but rather experienced the opening of a new lava lake. At Redoubt, three values in excess of 80 related to a period of $\mathrm{SO}_{2}$ scrubbing in the month prior to eruption were removed - see Ref. 141 for details. 

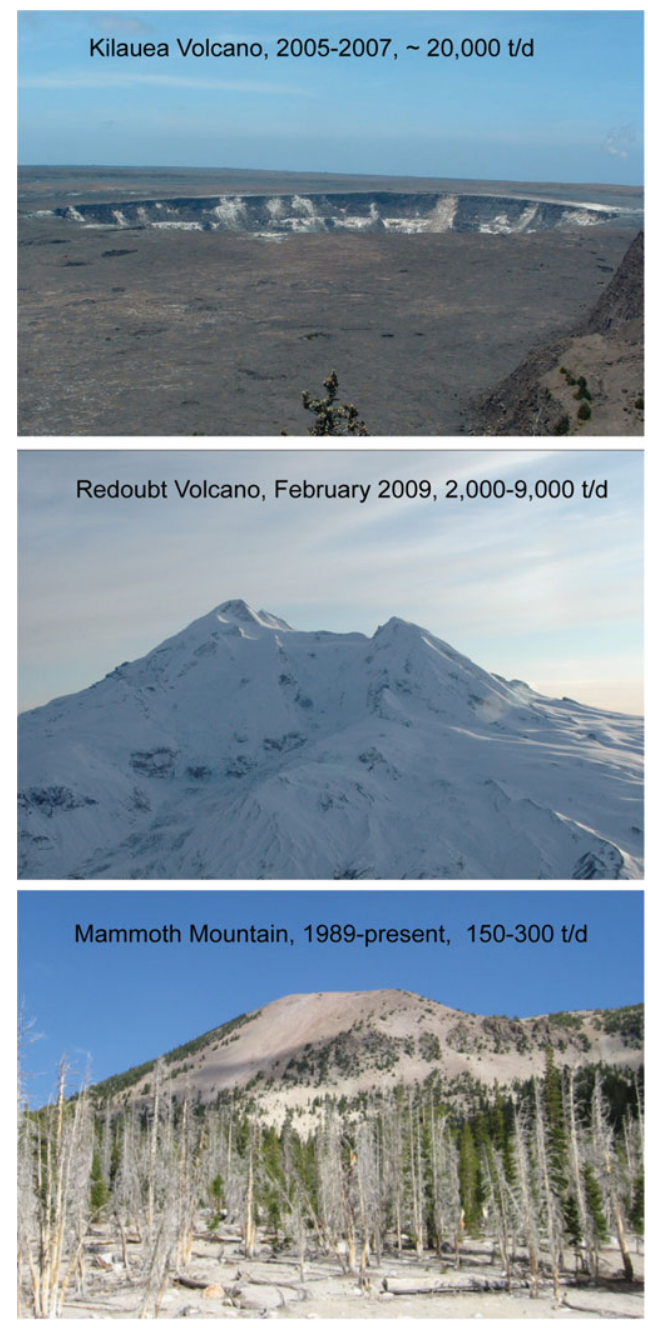

Figure 8.8 Images of volcanoes emitting significant quantities of volcanic $\mathrm{CO}_{2}$ in the absence of a visible plume.

continental lithosphere has been suggested as a mechanism for long-term carbon storage, removing the requirement for carbon subduction into the deeper mantle to balance the input versus output budgets at arcs. ${ }^{171}$ The extent to which this process occurs globally is poorly constrained, but it could significantly affect the carbon isotope composition of the mantle wedge and therefore the mantle component sampled by arc volcanic gases. Recently, researchers have highlighted, in addition to the subducted carbon source, the potential significance of carbon assimilation from the overlying crust in continental arc magmas as a major source of $\mathrm{CO}_{2}$ degassing from volcanoes, both today and in the geologic past. ${ }^{4,172,173}$ In particular, this crustally sourced carbon can have profound effects 
on the generation of arc magmas, ${ }^{174}$ the explosive activity of a volcano, ${ }^{173,175}$ and longterm climate change resulting from $\mathrm{CO}_{2}$ release into the atmosphere. ${ }^{172}$

The approach most commonly taken when assessing the contribution of volatiles from the crust is to use helium isotopes, which range widely in volcanic gases from values that approach pure crustal sources of $\sim 0.02 \mathrm{Ra}$, where $\mathrm{Ra}$ is the ${ }^{3} \mathrm{He} /{ }^{4} \mathrm{He}$ ratio of air at $1.4 \times 10^{-6}$, to $29 \mathrm{Ra}$ in fluids discharged from hot spot hydrothermal systems and volcanoes. ${ }^{176} \mathrm{In}$ subduction-zone settings, ${ }^{3} \mathrm{He} /{ }^{4} \mathrm{He}$ ratios of gas discharges range from the crustal value to $10 \mathrm{Ra},{ }^{176}$ with an unweighted average of $5.4 \mathrm{Ra}^{70} \mathrm{~A}$ recent compilation of maximum ${ }^{3} \mathrm{He} /{ }^{4} \mathrm{He}$ ratios of arc gases shows a global average of $7.4 \pm 1.5 \mathrm{Ra},{ }^{176}$ overlapping with the mid-ocean ridge basalt (MORB) value (Figure 8.9). The main process that lowers ${ }^{3} \mathrm{He} /{ }^{4} \mathrm{He}$ in arc gases is the contribution of ${ }^{4} \mathrm{He}$ from crustal sources through either magma assimilation of crustal rocks or interaction of magmatic fluids with crustal fluids at shallow depths. ${ }^{176}$ Such processes may also affect the carbon isotopic signature. Plotting the $\delta^{13} \mathrm{C}$ and ${ }^{3} \mathrm{He} /{ }^{4} \mathrm{He}$ of arc gases shows that: (1) very few samples plot in the DMM range for both helium and carbon, implying that subducted and/or crustal carbon affects the isotopic composition and the amount of $\mathrm{CO}_{2}$ at arc volcanoes; (2) samples where ${ }^{3} \mathrm{He} /{ }^{4} \mathrm{He}$ is $7 \pm 1 \mathrm{Ra}$ have $\delta^{13} \mathrm{C}$ values ranging from $+2 \%$ to $-12 \%$, implying that if the source of $\mathrm{CO}_{2}$ is from the subducted slab, it is sourced from both carbonates and organic carbon. Alternatively, the wide $\delta^{13} \mathrm{C}$ range for samples with $\mathrm{Ra}>7$ could be the result of modification of the mantle beneath arc volcanoes due to prior subduction events that affected carbon, but not helium; and (3) gases with ${ }^{3} \mathrm{He} /{ }^{4} \mathrm{He}$ values $<7$ Ra show an equally wide distribution of $\delta^{13} \mathrm{C}$ as those $>7 \mathrm{Ra}$, implying that both carbonate and organic carbon derived from the overlying crust (as implied by low ${ }^{3} \mathrm{He} /{ }^{4} \mathrm{He}$ ) may contribute to the degassing $\mathrm{CO}_{2}$.

Most helium and carbon isotope data are from low-temperature $\left(<100^{\circ} \mathrm{C}\right)$ bubbling springs and fumaroles, which can be affected by low-temperature carbon isotope fractionation in the crust and shallow hydrothermal systems. ${ }^{177,178}$ If we only consider $>200^{\circ} \mathrm{C}$ gases (Figure 8.9b), which are more likely to reflect their source, the range in $\delta^{13} \mathrm{C}$ remains from $-12 \%$ to $0 \%$ for both gases with ${ }^{3} \mathrm{He} /{ }^{4} \mathrm{He}$ values $>7$ and $<7 \mathrm{Ra}$, with the same implications as stated above.

Recently, a different approach has been used to evaluate the sources of carbon in volcanic emissions, using the $\mathrm{C} / \mathrm{S}$ ratio of volcanic gases in crater plumes and hightemperature $\left(>450^{\circ} \mathrm{C}\right)$ fumaroles. ${ }^{73}$ Selection of only high-temperature samples ensures that secondary hydrothermal processes do not affect the data set. The advantage of this approach is that many more data are available for C/S ratios than for isotope systematics, allowing for a more complete global coverage. Correlations with petrologic indicators of slab-derived fluids such as the $\mathrm{Ba} / \mathrm{La}$ ratios of erupted materials allows distinction between emissions that have predominantly crustally derived $\mathrm{CO}_{2}$ and emissions that show a strong subducted slab carbon component. ${ }^{73}$ This global data set further reveals that only some gases with high $\mathrm{C} / \mathrm{S}$ ratios $(>4)$ are from locations where volcanoes sit on upper-plate carbonates. The data set further shows that volcanoes with low $\mathrm{C} / \mathrm{S}$ ratios $(<2)$ are in locations where the subducting sediments contain only $<10 \% \mathrm{CO}_{2}$. This 
(a)

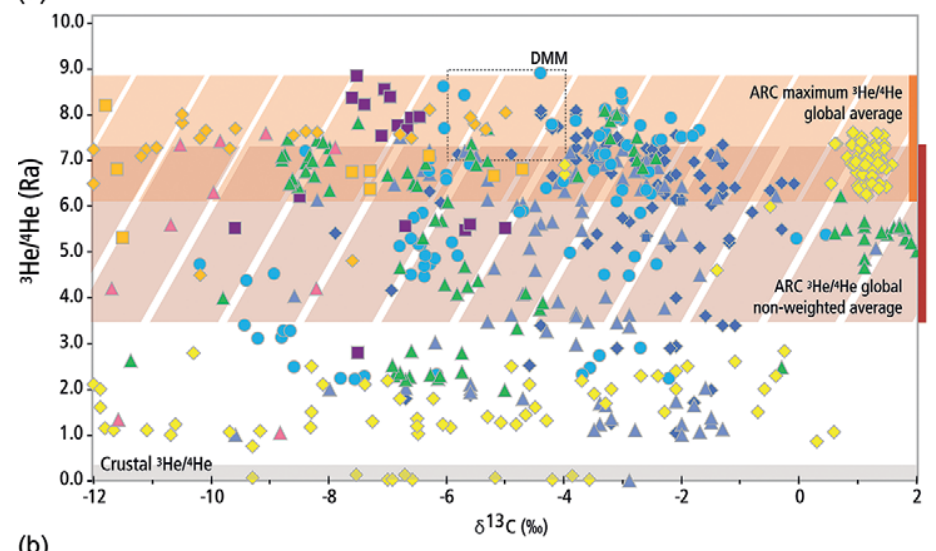

- Central America

- New Zealand

$\Delta$ Indonesia

- Lesser Antilles

- Northern Andes

Southern Andes

$\Delta$ Japan

Kuriles-Kamchatka

Italy

$\triangle$ Cascades

Aleutians

(b)

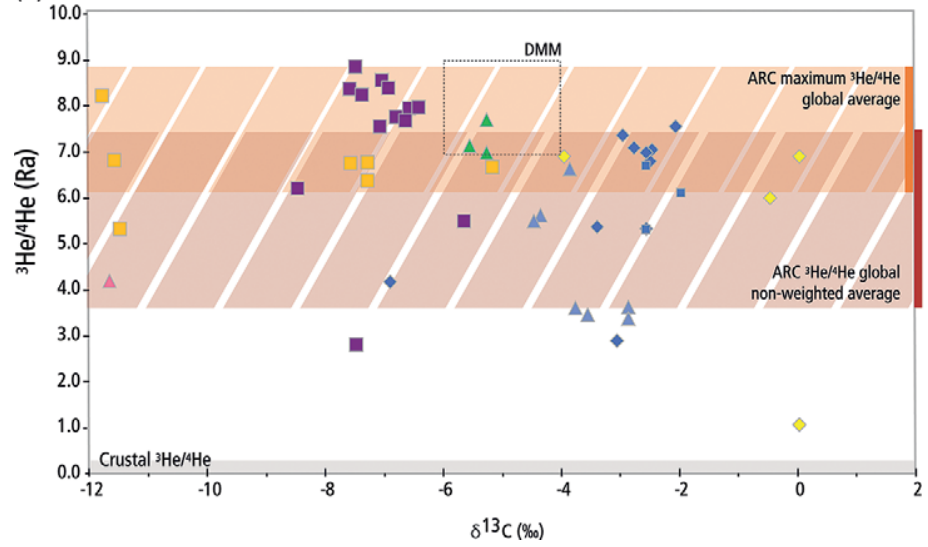

Figure 8.9 (a) Helium and carbon isotope signatures for volcanic and hydrothermal gas discharges and (b) data from discharges with vent temperatures $>200^{\circ} \mathrm{C}$. Data from Refs. 70 and 179-182. The field for DMM is from Refs. 162 and 163. The global data for arcs are from Ref. 70 and represent a non-weighted global average. The maximum global average for arcs is from Ref. 176 and represents the average of the maximum ${ }^{3} \mathrm{He} /{ }^{4} \mathrm{He}$ ratios measured at a given locality.

study shows that the carbon contribution from assimilation in the overriding crust may be significant in some localities (Italy, Indonesia, Central America, Lesser Antilles), but an important factor affecting the $\mathrm{C} / \mathrm{S}$ ratio and $\mathrm{CO}_{2}$ source in arc volcanoes is the subducting slab. As with the isotope approach, more work is needed since the C/S ratio in volcanic gas discharges is also significantly affected by volcanic activity, the presence of accumulated carbon-rich exsolved vapor in magma reservoirs, ${ }^{107}$ and degassing processes. Longterm records are thus needed to constrain the average and representative C/S ratio of a particular volcano. 


\subsection{Volcanic Release of $\mathrm{CO}_{2}$ over Geologic Time}

The modern-day volcanic carbon flux is a snapshot in time. We have shown that the modern-day flux of volcanic carbon could be dominated by the diffuse degassing of volcanic regions and large calderas (Figure 8.3b). Equally important for the global volcanic flux are a number of large volcanic point sources that represent Earth's most active volcanoes (Figure 8.3a); these volcanoes are in a range of geologic settings (arc, ocean island/mantle plume, continental rift).

Over 1-Ma timescales, the flux of volcanic carbon to Earth's surface is counteracted by the drawdown of $\mathrm{CO}_{2}$ by silicate weathering and the associated precipitation of marine carbonates, as well as the burial of organic carbon. Perturbations to carbon outgassing are compensated for by changes in the rate of silicate weathering (which is enhanced under conditions of high $\mathrm{pCO}_{2}$ and atmosphere temperature), keeping the surface reservoir approximately in balance. There have been periods through Earth history, however, when volcanism has been enhanced, causing perturbations to atmospheric $\mathrm{CO}_{2}$ that have persisted for a range of timescales. Although our study of modern volcanic carbon fluxes tells us little about the carbon cycle response to such perturbations in Earth's past, there are insights to be gained from modern observations of the magnitude of the flux from individual volcanoes and from larger regions, the nature of the flux (direct or diffuse), and its variability with time.

The processes of subduction, deep carbonated eclogite melting, ${ }^{5}$ and fluid addition to the subcontinental lithosphere from the convecting asthenosphere over time have led to the subcontinental lithosphere becoming a large carbon sink. ${ }^{183}$ Over Earth's past, supercontinents have accreted and broken apart. It has been recognized that periods of greenhouse climate correlate with supercontinents in the geological record, ${ }^{133,184}$ and this has been attributed to the prevalence of high-flux continental arc volcanoes, which may capture carbon not only from the downgoing slabs, but also from the devolatilization of carbonate platforms in the overlying continental crust. In the Cretaceous, for example, Gondwana's breakup led to the closure of the Tethys Ocean, accretion and subduction of marine carbonate platforms and the formation of a long subduction zone that may have been an important source of global volcanic $\mathrm{CO}_{2}^{4,172,185}$ (reviewed further in Chapter 11).

The results of our modern-day volcanic $\mathrm{CO}_{2}$ studies have shown, however, that the continental rifts themselves may also be important sources of carbon outgassing, which may in fact be larger than the surrounding continental arcs, certainly enhancing $\mathrm{CO}_{2}$ output and warming during the initial stages of continental breakup and providing a way for shortterm tectonics and volcanism to impact climate. ${ }^{183}$

\subsection{Synthesis}

Considerable progress has been made in the last decade in quantifying $\mathrm{CO}_{2}$ emissions from volcanic areas worldwide. Technological advances, including widespread use of miniturized UV spectometer systems and Multi-GAS instruments, have resulted in a greater 
number of $\mathrm{CO}_{2}$ measurements. Volcanic $\mathrm{CO}_{2}$ emissions have been measured for a few decades, which is short in terms of the eruptive cycles at many of Earth's volcanoes. Measurements are heavily biased toward eruptive periods, and average emissions for some active volcanoes are decreasing as longer records become available. Global satellite studies of decadal-scale $\mathrm{SO}_{2}$ emission from Earth's most active volcanoes, when combined with a complete $\mathrm{C} / \mathrm{S}$ data set, will allow for an accurate estimate of persistent $\mathrm{CO}_{2}$ degassing in the near future. We suggest the highest $10-20 \mathrm{SO}_{2}$-emitting volcanoes be prioritized for measurement as these volcanoes may dominate the total $\mathrm{CO}_{2}$ output from active volcanoes. $\mathrm{CO}_{2}$ emissions from volcanoes with $\mathrm{SO}_{2}$ output below satellite detection limits are not as well quantified, yet the emissions from these sources could be significant at a global scale. More work is needed to determine both the magnitude of these emissions and how widespread these volcanoes are globally.

Our knowledge of diffuse degassing at active and dormant volcanoes continues to improve. The distribution of diffuse fluxes is similar to the distribution of $\mathrm{CO}_{2}$ emissions from active volcanoes, and there are several areas worldwide with large, intrusive magma bodies where the diffuse fluxes are globally significant. More effort is needed to quantify emissions in these vast regions, as well as in the biggest 10-20 hydrothermal areas globally.

We summarize two decades of measurements at some well-studied volcanic systems that demonstrate that the slow release of $\mathrm{CO}_{2}$ from inactive or dormant volcanoes rivals that of active volcanoes when considered over long timescales. Regional volcanic $\mathrm{CO}_{2}$ fluxes are heavily influenced by individual volcanoes becoming more or less active, and thus measurements must be maintained over decadal scales to assess this variability quantitatively.

Vent emissions from active volcanoes vary by orders of magnitude over short (days to years) timescales, whereas diffuse emissions are largely buffered and show steadier rates through time. This variability is largely controlled by the plumbing of the volcanic systems. Active mafic volcanoes often host an open vent (with a free magma surface or lava lake) and volatiles are delivered rapidly to the surface, allowing for rapid variability. Larger silicic magmatic systems, sustained by the underplating of basaltic magmas, are characterized by steady diffuse outgassing over time.

Continuous Multi-GAS monitoring has improved eruption forecasting potential by showing that eruptions at mafic volcanoes are often preceded by an increase in the $\mathrm{C} / \mathrm{S}$ gas ratio in the days to months prior to eruption. Long-term monitoring of some volcanoes shows months-long changes in the $\mathrm{C} / \mathrm{S}$ ratio prior to eruption, and sometimes in the absence of eruption, which may accompany decompression of magma as it migrates from the lower to the upper crust. These later cases were often accompanied by the lack of a visible plume or $\mathrm{SO}_{2}$ emission, and thus more work is needed to identify when such plumes exist.

A fundamental challenge in carbon science is to constrain the deep global carbon budget and how much of the surface-derived carbon is recycled back into the mantle. In arc 
volcanoes, the source of volcanic $\mathrm{CO}_{2}$ is a combination of mantle and slab-derived $\mathrm{C}$ with a potentially significant crustal component, at least in some locations. A more complete understanding of the carbon balance at subduction zones requires quantification of the amount of carbon in the subducted lithologies. The pathways and fate of subducted carbon beyond the zones of arc magma generation determine where this carbon is ultimately stored and how it could potentially affect processes in different tectonic settings through time. While great progress has been made in terms of the quantification of carbon emissions from volcanic regions, more work is needed to constrain our understanding of the balance between surface and deep carbon through geologic time.

\subsection{Limits to Knowledge of Volcanic Carbon}

For all of the new data and understanding, significant gaps remain in our knowledge. Some of these gaps may persist, limited by technology or the logistics of measurement. The first gap in knowledge is caused by the lack of data for key volcanic systems. These include important point sources of volcanic $\mathrm{SO}_{2}$, such as Bagana, Tavurvur, and Manam (Papua New Guinea), as well as Aoba/Ambae (Vanuatu). Longer records are needed at most volcanoes globally to assess variability over decadal scales in relation to eruptive cycles and periods of repose. Better quantification of hydrothermal diffuse degassing is needed in areas already identified to be large $\mathrm{CO}_{2}$ emitters, such as Yellowstone (USA), the EAR (Africa), and the TVZ (New Zealand), and more measurements are needed in the vast regions of Southeast Asia and South America, where large hydrothermal systems exist. Further measurements are also needed in rifts such as the Eger Rift (Germany) and the Basin and Range (USA). Many of these targets are accessible, but require dedicated efforts over many years, and they would benefit from further technological development and improved measurement strategies. In this category we include global MORs and submarine back-arcs, for which only limited data exist. These measurements are logistically challenging, and it is unlikely that significant progress can be made without considerable effort and expense. More tractable approaches use primary melt geochemistry (Chapter 9) and geodynamic models to reconstruct $\mathrm{CO}_{2}$ budgets of submarine regions.

A fraction of the $\mathrm{CO}_{2}$ released from the degassing of silicate melts and directly from the mantle or crust may be dissolved into groundwaters and transported through aquifers, delivered to the surface via cold springs. This source of $\mathrm{CO}_{2}$ has not been quantified in most volcanic regions. Studies from central Italy have shown that significant quantities of inorganic carbon are dissolved in aquifers, derived from a mixture of biological sources, carbonate dissolution, and deep carbon sources.

Using the DECADE results thus far, it is possible to relate slab inputs at arc volcanoes to volcanic gas $\mathrm{C} / \mathrm{S}$ signatures and to identify arcs and individual volcanoes where $\mathrm{CO}_{2}$ rich crustal fluids play a significant role. However, much work remains to be done in linking magma geochemistry to the composition of outgassing fluids and for understanding the fate of devolatilized carbon in the mantle wedge and the behavior and dynamics of 
magma- and crust-derived fluids in vertically protracted, complex magma reservoirs in the crust. These studies require a range of approaches, including thermodynamic and analog modeling and building detailed databases of magma geochemistry and volcanic gas composition for detailed empirical comparisons. Understanding the amount of carbon returned to the deep mantle is of fundamental importance to the carbon budget of Earth through time. Linking our understanding of the present-day volcanic carbon budget to studies of plate tectonic reconstructions is an aim for the future and is explored further by Lee et al. in Chapter 11 of this book.

\section{Acknowledgments}

The work presented here has only been possible thanks to the enormous contributions made by the scientists and technicians in the volcano gas community in recent years. Funding provided by the Alfred P. Sloan Foundation through the Deep Carbon Observatory has enabled a significant amount of new research from many regions around the world. Funding for this chapter was provided by the US Geological Survey Volcano Hazards Program. The authors thank Josh Wood for his contribution in drafting Figures 8.1 and 8.7 and Jake Lowenstern and one anonymous reviewer for valuable reviews. The authors thank the following people for their assistance in obtaining publicly available $\mathrm{CO}_{2}$ emission rate data, hydrothermal location data, and helpful suggestions and refinements of the text: Robin Campion, Bruce Christenson, Maarten deMoor, Tamar Elias, Kohei Kazahaya, Ryunosuke Kazahaya, Peter Kelly, Christoph Kern, Taryn Lopez, Jennifer Lewicki, Agnes Mazot, Chris Newhall, Mitch Owen, Vicentina Cruz Pauccara, Jim Stimac, Jeff Sutton, and Yuri Taran. The research leading to some of the results some of the results presented received funding from the European Research Council under the European Union's Seventh Framework Programme (FP/2007-2013)/ERC Grant Agreement 279802, and RCUK NERC funding through the DisEqm project (NE/N018575/1).

\section{Questions for the Classroom}

1 How can we improve our estimates of volcanic $\mathrm{CO}_{2}$ emissions?

2 How can we quantify the $\mathrm{CO}_{2}$ contribution to the atmosphere from magmatic intrusions that do not lead to eruption and how can we better combine geophysical and geochemical studies to identify when such emissions occur?

3 What methods can advance our estimation of hydrothermal $\mathrm{CO}_{2}$ emissions?

4 How can we improve our knowledge of how many volcanoes are emitting $\mathrm{CO}_{2}$ in the absence of significant quantities of $\mathrm{SO}_{2}$ ?

5 How significant is $\mathrm{CO}_{2}$ degassing from magmas located at the base of the crust and how would we distinguish this from shallower magma degassing?

6 Can $\mathrm{CO}_{2}$ degas from the mantle without the presence of magma? 


\section{List of Online Resources}

- Eruptions, Earthquakes \& Emissions Application Citation: Global Volcanism Program, 2016. Eruptions, Earthquakes \& Emissions, v. 1.0 (Mobile application software). Smithsonian Institution. Accessed March 2018, retrieved from http://volcano.si.axismaps.io

- Carn, S. A., Fioletov, V. E., McLinden, C. A., Li, C. \& Krotkov, N. A. A decade of global volcanic $\mathrm{SO}_{2}$ emissions measured from space. Scientific Reports 7, 44095 (2017). Direct link: www.nature.com/articles/srep44095\#supplementary-information

- MaGa database: www.magadb.net

- EarthChem Library: www.earthchem.org/library

\section{References}

1. Kump, L. R. \& Barley, M. E. Increased subaerial volcanism and the rise of atmospheric oxygen 2.5 billion years ago. Nature 448, 1033-1036 (2007).

2. Berner, R. A. The Phanerozoic Carbon Cycle: $\mathrm{CO}_{2}$ and $\mathrm{O}_{2}$ (Oxford University Press, 2004).

3. Dasgupta, R. Ingassing, storage, and outgassing of terrestrial carbon through geologic time. In: Carbon in Earth, Vol. 75: Reviews in Mineralogy \& Geochemistry (eds. R. M. Hazen, A. P. Jones \& J. A. Baross), 183-229 (Mineralogical Society of America, 2013).

4. Mason, E., Edmonds, M. \& Turchyn, A. V. Remobilization of crustal carbon may dominate volcanic arc emissions. Science 357, 290-294 (2017).

5. Dasgupta, R. \& Hirschmann, M. M. The deep carbon cycle and melting in Earth's interior. Earth and Planetary Science Letters 298, 1-13 (2010).

6. Wood, B. J. Carbon in the core. Earth and Planetary Science Letters 117, 593-607 (1993).

7. Berner, R. A. Atmospheric carbon dioxide levels over Phanerozoic time. Science 249, 1382-1386 (1990).

8. Symonds, R. B., Rose, W. I., Bluth, G. S. \& Gerlach, T. M. Volcanic gas studies: methods, results, and applications. In: Volatiles in Magmas, Vol. 30 (eds. M. R. Carroll and J. R. Holloway), 1-60 (Mineralogical Society of America, 1994).

9. McCormick, B. T., Edmonds, M., Mather, T. A. \& Carn, S. A. First synoptic analysis of volcanic degassing in Papua New Guinea. Geochemistry, Geophysics, Geosystems 13, 3 (2012).

10. Gal, F., Leconte, S. \& Gadalia, A. The "Escarot" gas seep, French Massif Central: $\mathrm{CO}_{2}$ discharge from a quiescent volcanic system - characterization and quantification of gas emissions. Journal of Volcanology and Geothermal Research 353, 68-82 (2018).

11. Gerlach, T. M., Doukas, M. P., McGee, K. A. \& Kessler, R. Airborne detection of diffuse carbon dioxide emissions at Mammoth Mountains, California. Geophysical Research Letters 26, 3661-3664 (1999).

12. James, E. R., Manga, M. \& Rose, T. P. $\mathrm{CO}_{2}$ degassing in the Oregon cascades. Geology 27, 823-826 (1999).

13. Caliro, S., Chiodini, G., Avino, R., Cardellini, C. \& Frondini, F. Volcanic degassing at Somma-Vesuvio (Italy) inferred by chemical and isotopic signatures of groundwater. Applied Geochemistry 20, 1060-1076 (2005). 
14. Fischer, T. P. DEep CArbon DEgassing: the Deep Carbon Observatory DECADE Initiative. Mineralogical Magazine 77, 1089 (2013).

15. Burton, M., Sawyer, G. M. \& Granieri, D. Deep carbon emissions from volcanoes. In: Carbon in Earth. Reviews in Mineralogy and Geochemistry (eds. R. M. Hazen, A. P. Jones \& J. A. Baross), 323-354 (Mineralogical Society of America, 2013).

16. Chiodini, G., Cioni, R., Guidi, M., Raco, B. \& Marini, L. Soil $\mathrm{CO}_{2}$ flux measurements in volcanic and geothermal areas. Applied Geochemistry 13, 543-552 (1998).

17. Gerlach, T. M. et al. Application of the LI-COR $\mathrm{CO}_{2}$ analyzer to volcanic plumes: a case study, volcan Popocatepetl, Mexico, June 7 and 10, 1995. Journal of Geophysical Research 102, 8005-8019 (1997).

18. Shinohara, H. Excess degassing from volcanoes and its role on eruptive and intrusive activity. Reviews of Geophysics 46, RG4005 (2008).

19. McGonigle, A. J. S., Oppenheimer, C., Galle, B., Mather, T. A. \& Pyle, D. M. Walking traverse and scanning DOAS measurements of volcanic gas emission rates. Geophysical Research Letters 29, 1985 (2002).

20. Galle, B. et al. A miniaturised ultraviolet spectrometer for remote sensing of $\mathrm{SO}_{2}$ fluxes: a new tool for volcano surveillance. Journal of Volcanology and Geothermal Research 119, 241-254 (2003).

21. Allard, P. et al. Eruptive and diffuse emissions of $\mathrm{CO}_{2}$ from Mount Etna. Nature 351, 387-391 (1991).

22. Carn, S. A. \& Bluth, G. J. S. Prodigious sulfur dioxide emissions from Nyamuragira volcano, DR Congo. Geophysical Research Letters 30, 2211 (2003).

23. Allard, P., Burton, M., Sawyer, G. \& Bani, P. Degassing dynamics of basaltic lava lake at a top-ranking volatile emitter: Ambrym volcano, Vanuatu arc. Earth and Planetary Science Letters 448, 69-80 (2016).

24. Shinohara, H. A new technique to estimate volcanic gas composition; plume measurements with a portable multi-sensor system. Journal of Volcanology and Geothermal Research 143, 319-333 (2005).

25. Aiuppa, A., Federico, C., Giudice, G. \& Gurrieri, S. Chemical mapping of a fumarolic field: La Fossa Crater, Vulcano Island (Aeolian Islands, Italy). Geophysical Research Letters 32, 4 (2005).

26. Kern, C., Werner, C., Elias, T., Sutton, A. J. \& Lübcke, P. Applying UV cameras for $\mathrm{SO}_{2}$ detection to distant or optically thick volcanic plumes. Journal of Volcanology and Geothermal Research 262, 80-89 (2013).

27. Mori, T. et al. Effect of UV scattering on $\mathrm{SO}_{2}$ emission rate measurements. Geophysical Research Letters 33, L17315 (2006).

28. Kelly, P. J. et al. Long-term autonomous volcanic gas monitoring with Multi-GAS at Mount St. Helens, Washington, and Augustine Volcano. Alaska AGU Fall Meeting Abstracts, V23B-3095 (2015).

29. Kelly, P. J. et al. Rapid chemical evolution of tropospheric volcanic emissions from Redoubt Volcano, Alaska, based on observations of ozone and halogen-containing gases. Journal of Volcanology and Geothermal Research 259, 317-333 (2013).

30. Moussallam, Y. et al. Hydrogen emissions from Erebus volcano, Antarctica. Bulletin of Volcanology 74, 2109-2120 (2012).

31. Gerlach, T. M., McGee, K. A., Elias, T., Sutton, A. J. \& Doukas, M. P. Carbon dioxide emission rate of Kilauea Volcano: implications for primary magma and the summit reservoir. Journal of Geophysical Research: Solid Earth 107, 2189 (2002).

32. Werner, C., Christenson, B. W., Hagerty, M. \& Britten, K. Variability of volcanic gas emissions during a crater lake heating cycle at Ruapehu Volcano, New Zealand. Journal of Volcanology and Geothermal Research 154, 291-302 (2006). 
33. Werner, C. et al. Variability of passive gas emissions, seismicity, and deformation during crater lake growth at White Island Volcano, New Zealand, 2002-2006. Journal of Geophysical Research: Solid Earth 113, B01204 (2008).

34. Werner, C., Evans, W. C., Poland, M., Tucker, D. S. \& Doukas, M. P. Long-term changes in quiescent degassing at Mount Baker Volcano, Washington, USA; evidence for a stalled intrusion in 1975 and connection to a deep magma source. Journal of Volcanology and Geothermal Research 186, 379-386 (2009).

35. McGonigle, A. J. S. et al. Unmanned aerial vehicle measurements of volcanic carbon dioxide fluxes. Geophysical Research Letters 35, L06303 (2008).

36. Mori, T. et al. Volcanic plume measurements using a UAV for the 2014 Mt. Ontake eruption. Earth Planets and Space 68, 49 (2016).

37. Shinohara, H. Composition of volcanic gases emitted during repeating Vulcanian eruption stage of Shinmoedake, Kirishima volcano, Japan. Earth Planets and Space 65, 667-675 (2013).

38. Aiuppa, A. et al. New ground-based lidar enables volcanic $\mathrm{CO}_{2}$ flux measurements. Scientific Reports 5, 13614 (2015).

39. Queisser, M., Granieri, D. \& Burton, M. A new frontier in $\mathrm{CO}_{2}$ flux measurements using a highly portable DIAL laser system. Scientific Reports 6, 33834 (2016).

40. Werner, C., Brantley, S. L. \& Boomer, K. $\mathrm{CO}_{2}$ Emissions related to the Yellowstone volcanic system 2. Statistical sampling, total degassing, and transport mechanisms. Journal of Geophysical Research 105, 10831-10846 (2000).

41. Cardellini, C., Chiodini, G. \& Frondini, F. Application of stochastic simulation to $\mathrm{CO}_{2}$ flux from soil: mapping and quantification of gas release. Journal of Geophysical Research: Solid Earth 108, 2425 (2003).

42. Mazot, A. \& Bernard, A. $\mathrm{CO}_{2}$ degassing from volcanic lakes. In: Volcanic Lakes (eds. D. Rouwet, B. Christenson, F. Tassi \& J. Vandemeulebrouck), 341-354 (Springer, 2015).

43. Pérez, N. M. et al. Global $\mathrm{CO}_{2}$ emission from volcanic lakes. Geology 39, 235-238 (2011).

44. Werner, C. et al. Monitoring volcanic hazard using eddy covariance at Solfatara volcano, Naples, Italy. Earth and Planetary Science Letters 210, 561-577 (2003).

45. Werner, C., Wyngaard, J. C. \& Brantley, S. Eddy-correlation measurement of hydrothermal gases. Geophysical Research Letters 27, 2925-2929 (2000).

46. Lewicki, J., Fischer, M. L. \& Hilley, G. E. Six-week time series of eddy covariance $\mathrm{CO}_{2}$ flux at Mammoth Mountain, California: performance evaluation and role of meteorological forcing. Journal of Volcanology and Geothermal Research 171, 178-190 (2008).

47. Lewicki, J. L., Hilley, G. E., Dobeck, L. \& Marino, B. D. V. Eddy covariance imaging of diffuse volcanic $\mathrm{CO}_{2}$ emissions at Mammoth Mountain, CA, USA. Bulletin of Volcanology 74, 135-141 (2012).

48. Lewicki, J. L., Kelly, P. J., Bergfeld, D., Vaughan, R. G. \& Lowenstern, J. B. Monitoring gas and heat emissions at Norris Geyser Basin, Yellowstone National Park, USA based on a combined eddy covariance and Multi-GAS approach. Journal of Volcanology and Geothermal Research 347, 312-326 (2017).

49. Lewicki, J. L. \& Hilley, G. E. Multi-scale observations of the variability of magmatic $\mathrm{CO}_{2}$ emissions, Mammoth Mountain, CA, USA. Journal of Volcanology and Geothermal Research 284, 1-15 (2014).

50. Rose, T. P., Lee Davisson, M. \& Criss, R. E. Isotope hydrology of voluminous cold springs in fractured rock from an active volcanic region, northeastern California. Journal of Hydrology 179, 207-236 (1996). 
51. Aiuppa, A. et al. Forecasting Etna eruptions by real-time observation of volcanic gas composition. Geology 35, 1115-1118 (2007).

52. Galle, B. et al. Network for Observation of Volcanic and Atmospheric Change (NOVAC) - a global network for volcanic gas monitoring: network layout and instrument description. Journal of Geophysical Research-Atmospheres 115, D05304 (2010).

53. Aiuppa, A. et al. Unusually large magmatic $\mathrm{CO}_{2}$ gas emissions prior to a basaltic paroxysm. Geophysical Research Letters 37, L17303 (2010).

54. Aiuppa, A. et al. Total volatile flux from Mount Etna. Geophysical Research Letters 35, L24302 (2008).

55. de Moor, J. M. et al. Short-period volcanic gas precursors to phreatic eruptions: insights from Poás Volcano, Costa Rica. Earth and Planetary Science Letters 442, 218-227 (2016).

56. de Moor, J. M. et al. A new sulfur and carbon degassing inventory for the Southern Central American volcanic arc: the importance of accurate time-series datasets and possible tectonic processes responsible for temporal variations in arc-scale volatile emissions. Geochemistry, Geophysics, Geosystems 18, 4437-4468 (2017).

57. Shinohara, H. Volatile flux from subduction zone volcanoes: Insights from a detailed evaluation of the fluxes from volcanoes in Japan. Journal of Volcanology and Geothermal Research 268, 46-63 (2013).

58. Ilyinskaya, E. et al. Degassing regime of Hekla volcano 2012-2013. Geochimica et Cosmochimica Acta 159, 80-99 (2015).

59. Werner, C. et al. Magmatic degassing, lava dome extrusion, and explosions from Mount Cleveland volcano, Alaska, 2011-2015: insight into the continuous nature of volcanic activity over multi-year timescales. Journal of Volcanology and Geothermal Research 337, 98-110 (2017).

60. Pedone, M. et al. Volcanic $\mathrm{CO}_{2}$ flux measurement at Campi Flegrei by tunable diode laser absorption spectroscopy. Bulletin of Volcanology 76, 13 (2014).

61. Pedone, M. et al. Tunable diode laser measurements of hydrothermal/volcanic $\mathrm{CO}_{2}$ and implications for the global $\mathrm{CO}_{2}$ budget. Solid Earth 5, 1209-1221 (2014).

62. Pedone, M. et al. Total (fumarolic plus diffuse soil) $\mathrm{CO}_{2}$ output from Furnas volcano. Earth Planets and Space 67, 12 (2015).

63. Fiorani, L. et al. Early detection of volcanic hazard by lidar measurement of carbon dioxide. Natural Hazards 83, S21-S29 (2016).

64. Queisser, M., Burton, M., Allan, G. R. \& Chiarugi, A. Portable laser spectrometer for airborne and ground-based remote sensing of geological $\mathrm{CO}_{2}$ emissions. Optics Letters 42, 2782-2785 (2017).

65. Werner, C. et al. Degassing of $\mathrm{CO}_{2}, \mathrm{SO}_{2}$, and $\mathrm{H}_{2} \mathrm{~S}$ associated with the 2009 eruption of Redoubt Volcano, Alaska. Journal of Volcanology and Geothermal Research 259, 270-284 (2013).

66. Schwandner, F. M. et al. Spaceborne detection of localized carbon dioxide sources. Science 358, eaam5782 (2017).

67. Gerlach, T. M. Present-day carbon dioxide emissions from volcanos. Earth in Space 4, 5 (1991).

68. Brantley, S. L. \& Koepenick, K. W. Measured carbon dioxide emissions from Oldoinyo Lengai and the skewed distribution of passive volcanic fluxes. Geology 23, 933-936 (1995).

69. Williams, S. N., Schaefer, S. J., Calvache, V. M. L. \& Lopez, D. Global carbon dioxide emission to the atmosphere by volcanoes. Geochimica et Cosmochimica Acta 56, 1765-1770 (1992). 
70. Hilton, D. R., Fischer, T. \& Marty, B. Noble gases and volatile recycling at subduction zones. Reviews in Mineralogy and Geochemistry 47, 319-370 (2002).

71. Andres, R. J. et al. A summary of sulfur-dioxide emission rate measurements from Guatemalan volcanos. Bulletin of Volcanology 55, 379-388 (1993).

72. Stoiber, R. E., Williams, S. N. \& Huebert, B. Annual contribution of sulfur dioxide to the atmosphere by volcanoes. Journal of Volcanology and Geothermal Research 33, 1-8 (1987).

73. Aiuppa, A., Fischer, T. P., Plank, T., Robidoux, P. \& Di Napoli, R. Along-arc, interarc and arc-to-arc variations in volcanic gas $\mathrm{CO}_{2} / \mathrm{S}$-T ratios reveal dual source of carbon in arc volcanism. Earth Science Reviews 168, 24-47 (2017).

74. Fischer, T. P. Fluxes of volatiles $\left(\mathrm{H}_{2} \mathrm{O}, \mathrm{CO}_{2}, \mathrm{~N}_{2}, \mathrm{Cl}, \mathrm{F}\right)$ from arc volcanoes. Geochemical Journal 42, 21-38 (2008).

75. Carn, S. A., Fioletov, V. E., McLinden, C. A., Li, C. \& Krotkov, N. A. A decade of global volcanic $\mathrm{SO}_{2}$ emissions measured from space. Scientific Reports 7, 44095 (2017).

76. Siebert, L., Simkin, T. \& Kimberly, P. Volcanoes of the World, 3rd edn. (University of California Press, 2010). https://doi.org/10.5479/si.GVP.VOTW4-2013.

77. Carn, S. A., Clarisse, L. \& Prata, A. J. Multi-decadal satellite measurements of global volcanic degassing. Journal of Volcanology and Geothermal Research 311, 99-134 (2016).

78. Torgersen, T. Terrestrial helium degassing fluxes and the atmospheric helium budget: Implications with respect to the degassing processes of continental crust. Chemical Geology: Isotope Geoscience Section 79, 1-14 (1989).

79. Sano, Y. \& Williams, S. N. Fluxes of mantle and subducted carbon along convergent plate boundaries. Geophysical Research Letters 23, 2749-2752 (1996).

80. Crisp, J. A. Rates of magma emplacement and volcanic output. Journal of Volcanology and Geothermal Research 20, 177-211 (1984).

81. Dimalanta, C., Taira, A., Yumul, G. P., Tokuyama, H. \& Mochizuki, K. New rates of western Pacific island arc magmatism from seismic and gravity data. Earth and Planetary Science Letters 202, 105-115 (2002).

82. Reymer, A. \& Schubert, G. Phanerozoic addition rates to the continental crust and crustal growth. Tectonics 3, 63-77 (1984).

83. Bianchi, D. et al. Low helium flux from the mantle inferred from simulations of oceanic helium isotope data. Earth and Planetary Science Letters 297, 379-386 (2010).

84. Kagoshima, T. et al. Sulphur geodynamic cycle. Scientific Reports 5, 8330 (2015).

85. Siebert, L. \& Simkin, T. Volcanoes of the world: an illustrated catalog of holocene volcanoes and their eruptions. Smithsonian Institution. Global volcanism program digital information series, GVP-3 (https://doi.org/10.5479/si.GVP.VOTW4-2013) (2002).

86. Bobrowski, N. et al. Multi-component gas emission measurements of the active lava lake of Nyiragongo, DR Congo. Journal of African Earth Sciences 134, 856-865 (2017).

87. Sawyer, G. M., Carn, S. A., Tsanev, V. I., Oppenheimer, C. \& Burton, M. Investigation into magma degassing at Nyiragongo volcano, Democratic Republic of the Congo. Geochemistry, Geophysics, Geosystems 9, Q02017 (2008).

88. Le Guern, F. Mechanism of energy-transfer in the lava lake of Niragongo (Zaire), 1959-1977. Journal of Volcanology and Geothermal Research 31, 17-31 (1987).

89. Kazahaya, K. et al. Gigantic $\mathrm{SO}_{2}$ emission from Miyakejima volcano, Japan, caused by caldera collapse. Geology 32, 425-428 (2004). 
90. Shinohara, H., Kazahaya, K., Saito, G., Fukui, K. \& Odai, M. Variation of $\mathrm{CO}_{2}-\mathrm{SO}_{2}$ ratio in volcanic plumes of Miyakejima; stable degassing deduced from heliborne measurements. Geophysical Research Letters 30, 4 (2003).

91. Doukas, M. P. \& McGee, K. A. A Compilation of Gas Emission-Rate Data from Volcanoes of Cook Inlet (Spurr, Crater Peak, Redoubt, Iliamna, and Augustine) and Alaska Peninsula (Douglas, Fourpeaked, Griggs, Mageik, Martin, Peulik, Ukinrek Maars, and Veniaminof ), Alaska, from 1995-2006. Open File Report, report number 2007-1400 (US Geological Survey, 2007).

92. Werner, C. A., Doukas, M. P. \& Kelly, P. J. Gas emissions from failed and actual eruptions from Cook Inlet Volcanoes, Alaska, 1989-2006. Bulletin of Volcanology 73, 155-173 (2011).

93. Kelly, P., Werner, C., Kem, C., Clor, L. E. \& Doukas, M. A compilation of airborne gas emissions data from Alaskan volcanoes. USGS Data Release (2019).

94. Christenson, B. W. et al. Cyclic processes and factors leading to phreatic eruption events: insights from the 25 September 2007 eruption through Ruapehu Crater Lake, New Zealand. Journal of Volcanology and Geothermal Research 191, 15-32 (2010).

95. Kilgour, G. N. et al. Timescales of magmatic processes at Ruapehu volcano from diffusion chronometry and their comparison to monitoring data. Journal of Volcanology and Geothermal Research 288, 62-75 (2014).

96. Elias, T. \& Sutton, A. J. Volcanic Air Pollution Hazards in Hawaii. Fact Sheet No. 2017-3017 (US Geological Survey, 2017).

97. Global Volcanism Program. Volcanoes of the World, v. 4.7.7 (Smithsonian Institution, 2013). https://doi.org/10.5479/si.GVP.VOTW4-2013.

98. Passarelli, L. \& Brodsky, E. E. The correlation between run-up and repose times of volcanic eruptions. Geophysical Journal International 188, 1025-1045 (2012).

99. Allard, P., Burton, M., Oskarsson, N., Michel, A. \& Polacci, M. Chemistry and fluxes of magmatic gases driving the explosive trachyandesitic phase of Eyjafjallajökull 2010 eruption: constraints on degassing magma volumes and processes. In: AGU Fall Meeting, V53F-07 (AGU, 2010).

100. Gerlach, T. M., Westrich, H. R. \& Symonds, R. B. Preeruption vapor in magma of the climactic Mount Pinatubo eruption: source of the giant stratospheric sulfur dioxide cloud. In: Fire and Mud: Eruptions and Lahars of Mount Pinatubo, Philippines (eds. C. G. Newhall \& R. S. Punongbayan), 415-434 (University of Washington Press, 1996).

101. Hobbs, P. V., Tuell, J. P., Hegg, D. A., Radke, L. F. \& Eltgroth, M. W. Particles and gases in the emissions from the 1980-1981 volcanic eruptions of Mt. St. Helens. Journal of Geophysical Research 87, 11062-11086 (1982).

102. Scaillet, B. \& Pichavant, M. Experimental constraints on volatile abundances in arc magmas and their implications for degassing processes. Geological Society Special Publications 213, 23-52 (2003).

103. Gerlach, T. M. Volcanic versus anthropogenic carbon dioxide. EOS Transactions $\mathbf{9 2 ,}$ 201-208 (2011).

104. Holloway, J. R. Fluids in the evolution of granitic magma: consequences of finite $\mathrm{CO}_{2}$ solubility. Geological Society of America Bulletin 87, 1513-1518 (1976).

105. Christopher, T. E. et al. Crustal-scale degassing due to magma system destabilization and magma-gas decoupling at Soufriere Hills Volcano, Montserrat. Geochemistry, Geophysics, Geosystems 16, 2797-2811 (2015).

106. Parmigiani, A., Faroughi, S., Huber, C., Bachmann, O. \& Su, Y. Bubble accumulation and its role in the evolution of magma reservoirs in the upper crust. Nature 532, 492-495 (2016). 
107. Burgisser, A., Alletti, M. \& Scaillet, B. Simulating the behavior of volatiles belonging to the $\mathrm{C}-\mathrm{O}-\mathrm{H}-\mathrm{S}$ system in silicate melts under magmatic conditions with the software D-Compress. Computers \& Geosciences 79, 1-14 (2015).

108. Kilbride, B. M., Edmonds, M. \& Biggs, J. Observing eruptions of gas-rich compressible magmas from space. Nature Communications 7, 13744 (2016).

109. Wallace, P. J. Volcanic $\mathrm{SO}_{2}$ emissions and the abundance and distribution of exsolved gas in magma bodies. Journal of Volcanology and Geothermal Research 108, 85-106 (2001).

110. Kerrick, D. M. Present and past non-anthropogenic $\mathrm{CO}_{2}$ degassing from the solid Earth. Reviews of Geophysics 39, 565-585 (2001).

111. Morner, N. A. \& Etiope, G. Carbon degassing from the lithosphere. Global and Planetary Change 33, 185-203 (2002).

112. Mori, T. et al. Time-averaged $\mathrm{SO}_{2}$ fluxes of subduction-zone volcanoes: example of a 32-year exhaustive survey for Japanese volcanoes. Journal of Geophysical Research - Atmospheres 118, 8662-8674 (2013).

113. Stimac, J., Goff, F. \& Goff, C. J. Intrusion-related geothermal systems. In: The Encyclopedia of Volcanoes, 2nd edn. (eds. H. Sigurdsson, B. Houghton, S. McNutt, H. Rymer \& J. Stix), 799-822 (Academic Press, 2015).

114. Cardellini, C. et al. MAGA, a new database of gas natural emissions: a collaborative webenvironment for collecting data. Geophysical Research Abstracts 16, EGU201413715 (2014).

115. Casadevall, T. J., Doukas, M. P., Neal, C. A., McGimsey, R. G. \& Gardner, C. A. Emission rates of sulfur dioxide and carbon dioxide from Redoubt Volcano, Alaska during the 1989-1990 eruptions. Journal of Volcanology and Geothermal Research 62, 519-530 (1994).

116. Werner, C. et al. Decadal-scale variability of diffuse $\mathrm{CO}_{2}$ emissions and seismicity revealed from long-term monitoring (1995-2013) at Mammoth Mountain, California, USA. Journal of Volcanology and Geothermal Research 289, 51-63 (2014).

117. Cardellini, C. et al. Monitoring diffuse volcanic degassing during volcanic unrests: the case of Campi Flegrei (Italy). Scientific Reports 7, 15 (2017).

118. Aiuppa, A. et al. Volcanic gas plume data from Stromboli Volcano (Italy). Interdisciplinary Earth Data Alliance (IEDA). doi:10.1594/IEDA/100643.

119. Christenson, B. W., White, S., Britten, K. \& Scott, B. J. Hydrological evolution and chemical structure of a hyper-acidic spring-lake system on Whakaari/White Island, NZ. Journal of Volcanology and Geothermal Research 346, 180-211 (2017).

120. Bloomberg, S. et al. Soil $\mathrm{CO}_{2}$ emissions as a proxy for heat and mass flow assessment, Taupō Volcanic Zone, New Zealand. Geochemistry, Geophysics, Geosystems 15, 4885-4904 (2014).

121. Mazot, A. et al. $\mathrm{CO}_{2}$ discharge from the bottom of volcanic Lake Rotomahana, New Zealand. Geochemistry, Geophysics, Geosystems 15, 577-588 (2014).

122. Rissmann, C. et al. Surface heat flow and $\mathrm{CO}_{2}$ emissions within the Ohaaki hydrothermal field, Taupo Volcanic Zone, New Zealand. Applied Geochemistry 27, 223-239 (2012).

123. Werner, C. \& Cardellini, C. Comparison of carbon dioxide emissions with fluid upflow, chemistry, and geologic structures at the Rotorua geothermal system, New Zealand. Geothermics 35, 221-238 (2006).

124. Acocella, V., Di Lorenzo, R., Newhall, C. \& Scandone, R. An overview of recent (1988 to 2014) caldera unrest: knowledge and perspectives. Reviews of Geophysics 53, 896-955 (2015). 
125. Newhall, C. G. \& Dzurisin, D. Historical Unrest at Large Calderas of the World. USGS Bulletin No. 1855 (USGS, 1988).

126. Chiodini, G. et al. Magmas near the critical degassing pressure drive volcanic unrest towards a critical state. Nature Communications 7, 13712 (2016).

127. Seward, T. M. \& Kerrick, D. M. Hydrothermal $\mathrm{CO}_{2}$ emission from the Taupo volcanic zone, New Zealand. Earth and Planetary Science Letters 139, 105-113 (1996).

128. Werner, C. \& Brantley, S. $\mathrm{CO}_{2}$ emissions from the Yellowstone volcanic system. Geochemistry, Geophysics, Geosystems 4, 1061 (2003).

129. Hurwitz, S. \& Lowenstern, J. B. Dynamics of the Yellowstone hydrothermal system. Reviews of Geophysics 52, 375-411 (2014).

130. Chiodini, G. et al. $\mathrm{CO}_{2}$ degassing and energy release at Solfatara volcano, Campi Flegrei, Italy. Journal of Geophysical Research: Solid Earth 106, 16213-16221 (2001).

131. Chiodini, G. et al. Carbon dioxide Earth degassing and seismogenesis in central and southern Italy. Geophysical Research Letters 31, L07615 (2004).

132. Frondini, F. et al. Measurement of $\mathrm{CO}_{2}$ fluxes at regional scale: the case of Apennines, Italy. Journal of the Geological Society 176, 408-416 (2019).

133. Lee, H. et al. Massive and prolonged deep carbon emissions associated with continental rifting. Nature Geoscience 9, 145-149 (2016).

134. Hunt, J. A., Zafu, A., Mather, T. A., Pyle, D. M. \& Barry, P. H. Spatially variable $\mathrm{CO}_{2}$ degassing in the Main Ethiopian Rift: implications for magma storage, volatile transport, and rift-related emissions. Geochemistry, Geophysics, Geosystems 18, 3714-3737 (2017).

135. World Energy Council. World Energy Resources 2016. www.worldenergy.org/wp-con tent/uploads/2016/10/World-Energy-Resources-Full-report-2016.10.03.pdf (2016).

136. Bibby, H., Caldwell, T. G., Davey, F. J. \& Webb, T. H. Geophysical evidence on the structure of the Taupo Volcanic Zone and its hydrothermal circulation. Journal of Volcanology and Geothermal Research 68, 29-58 (1995).

137. Chiodini, G. et al. Carbon dioxide diffuse emission and thermal energy release from hydrothermal systems at Copahue-Caviahue Volcanic Complex (Argentina). Journal of Volcanology and Geothermal Research 304, 294-303 (2015).

138. Omenda, P. A. The geothermal activity of the East African Rift, in Short Course IV on Exploration for Geothermal Resources, organized by UNU-GTP, KenGen and GDC (ed. UNU-GTP). https://orkustofnun.is/gogn/unu-gtp-sc/UNU-GTP-SC-100204.pdf.

139. Moran, S. C. et al. Instrumentation Recommendations for Volcano Monitoring at U.S. Volcanoes Under the National Volcano Early Warning System. US Geological Survey Scientific Investigations Report No. 2008-5114 (USGS, 2008).

140. Poland, M. P., Miklius, A., Jeff Sutton, A. \& Thornber, C. R. A mantle-driven surge in magma supply to Kīlauea Volcano during 2003-2007. Nature Geoscience 5, 295 (2012).

141. Werner, C. et al. Deep magmatic degassing versus scrubbing: elevated $\mathrm{CO}_{2}$ emissions and C/S in the lead-up to the 2009 eruption of Redoubt Volcano, Alaska. Geochemistry, Geophysics, Geosystems 13, Q03015 (2012).

142. Ilyinskaya, E. et al. Globally significant $\mathrm{CO}_{2}$ emissions From Katla, a subglacial volcano in Iceland. Geophysical Research Letters 45, 10332-10341 (2018).

143. Carn, S. A. Multi-Satellite Volcanic Sulfur Dioxide L4 Long-Term Global Database V2. doi:10.5067/MEASURES/SO2/DATA402. 
144. Marty, B. \& Tolstikhin, I. N. $\mathrm{CO}_{2}$ fluxes from mid-ocean ridges, arcs and plumes. Chemical Geology 145, 233-248 (1998).

145. Aiuppa, A. et al. The 2007 eruption of Stromboli volcano: Insights from real-time measurement of the volcanic gas plume $\mathrm{CO}_{2} / \mathrm{SO}_{2}$ ratio. Journal of Volcanology and Geothermal Research 182, 221-230 (2009).

146. Aiuppa, A. et al. A model of degassing for Stromboli Volcano. Earth and Planetary Science Letters 295, 195-204 (2010).

147. Kazahaya, K., Shinohara, H. \& Saito, G. Excessive degassing of Izu-Oshima Volcano; magma convection in a conduit. Bulletin of Volcanology 56, 207-216 (1994).

148. Aiuppa, A. et al. Volcanic gas plume data from Etna Volcano (Italy). Interdisciplinary Earth Data Alliance (IEDA). doi:10.1594/IEDA/100643.

149. McGee, K. A. The structure, dynamics, and chemical composition of noneruptive plumes from Mount St. Helens, 1980-1988. Journal of Volcanology and Geothermal Research 51, 269-282 (1992).

150. Chiodini, G. et al. Magma degassing as a trigger of bradyseismic events: the case of Phlegrean Fields (Italy). Geophysical Research Letters 30, 1434 (2003).

151. Giggenbach, W. Variations in the carbon, sulfur and chlorine contents of volcanic gas discharges from White Island, New Zealand. Bulletin of Volcanology 39, 15-27 (1975).

152. Fischer, T. P., Arehart, G. B., Sturchio, N. C. \& Williams, S. N. The relationship between fumarole gas composition and eruptive activity at Galeras volcano, Colombia. Geology 24, 531-534 (1996).

153. Dixon, J. E. \& Stolper, E. M. An experimental study of water and carbon dioxide solubilities in mid-ocean ridge basaltic liquids. 2. Applications to degassing. Journal of Petrology 36, 1633-1646 (1995).

154. Aiuppa, A. et al. Tracking Formation of a Lava Lake From Ground and Space: Masaya Volcano (Nicaragua), 2014-2017. Geochemistry, Geophysics, Geosystems 19, 496-515 (2018).

155. Aiuppa, A. et al. $\mathrm{A} \mathrm{CO}_{2}$-gas precursor to the March 2015 Villarrica volcano eruption. Geochemistry, Geophysics, Geosystems 18, 2120-2132 (2017).

156. de Moor, J. M. et al. Turmoil at Turrialba Volcano (Costa Rica): degassing and eruptive processes inferred from high-frequency gas monitoring. Journal of Geophysical Research: Solid Earth 121, 5761-5775 (2016).

157. Pfeffer, M. et al. Ground-Based Measurements of the 2014-2015 Holuhraun Volcanic Cloud (Iceland). Geosciences 8, 29 (2018).

158. Allard, P. Composition isotopique du carbonne dans les gas d'un volcan d'arc: le Momotombo (Nicaragua). Comptes rendus de l'Académie des Sciences 290, 1525-1528 (1980).

159. Allard, P. Stable isotope composition of hydrogen, carbon and sulphur in magmatic gases from rift and island arc volcanoes. Bulletin of Volcanology 45, 269-271 (1982).

160. Allard, P. The origin of hydrogen, carbon, sulfur, nitrogen and rare gases in volcanic exhalations: evidence from isotope geochemistry. In: Forecasting Volcanic Events, Vol. 1 (eds. H. Tazieff \& J. Sabroux), 337-386 (Elsevier, 1983).

161. Marty, B. \& Jambon, A. $\mathrm{C} /^{3} \mathrm{He}$ in volatile fluxes from the solid Earth; implications for carbon geodynamics. Earth and Planetary Science Letters 83, 16-26 (1987).

162. Marty, B., Jambon, A. \& Sano, Y. Helium isotopes and $\mathrm{CO}_{2}$ in volcanic gases of Japan. Chemical Geology 76, 25-40 (1989).

163. Cartigny, P., Jendrzejewski, N., Pineau, F., Petit, E. \& Javoy, M. Volatile (C, N, Ar) variability in MORB and the respective roles of mantle source heterogeneity and 
degassing: the case of the Southwest Indian Ridge. Earth and Planetary Science Letters 194, 241-257 (2001).

164. Marty, B. \& Zimmermann, L. Volatiles (He, C, N, Ar) in mid-ocean ridge basalts: assesment of shallow-level fractionation and characterization of source composition. Geochimica et Cosmochimica Acta 63, 3619-3633 (1999).

165. Barry, P. H., Hilton, D. R., Füri, E., Halldórsson, S. A. \& Grönvold, K. Carbon isotope and abundance systematics of Icelandic geothermal gases, fluids and subglacial basalts with implications for mantle plume-related $\mathrm{CO}_{2}$ fluxes. Geochimica et Cosmochimica Acta 134, 74-99 (2014).

166. Gerlach, T. M. \& Taylor, B. E. Carbon isotope constraints on degassing of carbon dioxide from Kilauea Volcano. Geochemica et Cosmochimica Acta 54, 2051-2058 (1990).

167. Fischer, T. P. et al. Upper-mantle volatile chemistry at Oldoinyo Lengai volcano and the origin of carbonatites. Nature 459, 77-80 (2009).

168. Barry, P. H. et al. Helium and carbon isotope systematics of cold "mazuku" $\mathrm{CO}_{2}$ vents and hydrothermal gases and fluids from Rungwe Volcanic Province, southern Tanzania. Chemical Geology 339, 141-156 (2013).

169. de Leeuw, G. A. M., Hilton, D. R., Fischer, T. P. \& Walker, J. A. The He-CO isotope and relative abundance characteristics of geothermal fluids in El Salvador and Honduras: new constraints on volatile mass balance of the Central American Volcanic Arc. Earth and Planetary Science Letters 258, 132-146 (2007).

170. Shaw, A. M., Hilton, D. R., Fischer, T. P., Walker, J. A. \& Alvarado, G. E. Contrasting $\mathrm{He}-\mathrm{C}$ relationships in Nicaragua and Costa Rica: insights into C cycling through subduction zones. Earth and Planetary Science Letters 214, 499-513 (2003).

171. Kelemen, P. B. \& Manning, C. E. Reevaluating carbon fluxes in subduction zones, what goes down, mostly comes up. Proceedings of the National Academy of Sciences of the United States of America 112, E3997-E4006 (2015).

172. Lee, C. T. A. et al. Continental arc-island arc fluctuations, growth of crustal carbonates, and long-term climate change. Geosphere 9, 21-36 (2013).

173. Troll, V. R. et al. Crustal $\mathrm{CO}_{2}$ liberation during the 2006 eruption and earthquake events at Merapi volcano, Indonesia. Geophysical Research Letters 39, L11302 (2012).

174. Carter, L. B. \& Dasgupta, R. Effect of melt composition on crustal carbonate assimilation: implications for the transition from calcite consumption to skarnification and associated $\mathrm{CO}_{2}$ degassing. Geochemistry, Geophysics, Geosystems 17, 3893-3916 (2016).

175. Deegan, F. M. et al. Magma-carbonate interaction processes and associated $\mathrm{CO}_{2}$ release at Merapi volcano, Indonesia: insights from experimental petrology. Journal of Petrology 51, 1027-1051 (2010).

176. Sano, Y. \& Fischer, T. P. The analysis and interpretation of noble gases in modern hydrothermal systems. In: Noble Gases as Geochemical Tracers (ed. P. Burnard), 249-317 (Springer Verlag, 2013).

177. Ray, M. C., Hilton, D. R., Munoz, J., Fischer, T. P. \& Shaw, A. M. The effects of volatile recycling, degassing and crustal contamination on the helium and carbon geochemistry of hydrothermal fluids from the Southern Volcanic Zone of Chile. Chemical Geology 266, 38-49 (2009).

178. van Soest, M. C., Hilton, D. R. \& Kreulen, R. Tracing crustal and slab contributions to arc magmatism in the Lesser Antilles island arc using helium and carbon relationships in geothermal fluids. Geochim.Cosmochim. Acta 62, 3323-3335 (1998). 
179. Evans, W. C. et al. Aleutian Arc Geothermal Fluids: Chemical Analyses of Waters and Gases. US Geological Survey Data release (USGS, 2015).

180. Motyka, R. J., Liss, S. A., Nye, C. J. \& Moorman, M. A. Geothermal Resources of the Aleutian Arc (Alaska Division of Geological \& Geophysical Surveys, 1994).

181. Oppenheimer, C., Fischer, T. P. \& Scaillet, B. Volcanic degassing: process and impact. In: Treatise on Geochemistry, 2nd edn. (ed. K. K. Turekian), 111-179 (Elsevier, 2014).

182. Symonds, R. B. et al. Scrubbing Masks Magmatic Degassing during Repose at CascadeRange and Aleutian-Arc Volcanoes. Open-File Report 2003-435 (USGS, 2003).

183. Foley, S. F. \& Fischer, T. P. An essential role for continental rifts and lithosphere in the deep carbon cycle. Nature Geoscience 10, 897-902 (2017).

184. McKenzie, N. R. et al. Continental arc volcanism as the principal driver of icehousegreenhouse variability. Science 352, 444-447 (2016).

185. Lee, C. T. A., Thurner, S., Paterson, S. \& Cao, W. R. The rise and fall of continental arcs: interplays between magmatism, uplift, weathering, and climate. Earth and Planetary Science Letters 425, 105-119 (2015).

186. Allard, P. et al. Prodigious emission rates and magma degassing budget of major, trace and radioactive volatile species from Ambrym basaltic volcano, Vanuatu island Arc. Journal of Volcanology and Geothermal Research 322, 119-143 (2016).

187. Mailik, N. Temperature and gas composition of the Avachinsky volcano fumaroles (Kamchatka) in 2013-2017. In: 13th CCVG-IAVCEI Gas Workshop (CCVG-IAVCEI, 2017).

188. Burton, $\mathrm{M}$. et al. New constraints on volcanic $\mathrm{CO}_{2}$ emissions from Java, Indonesia. Geophysical Research Abstracts 20, EGU2018-15195 (2018).

189. Taran, Y. et al. Gas emissions from volcanoes of the Kuril Island Arc (NW Pacific): geochemistry and fluxes. Geochemistry, Geophysics, Geosystems 19, 1859-1880 (2018).

190. Aiuppa, A. et al. First determination of magma-derived gas emissions from Bromo volcano, eastern Java (Indonesia). Journal of Volcanology and Geothermal Research 304, 206-213 (2015).

191. Tamburello, G. et al. Intense magmatic degassing through the lake of Copahue volcano, 2013-2014. Journal of Geophysical Research: Solid Earth 120, 6071-6084 (2015).

192. Bani, P. et al. Dukono, the predominant source of volcanic degassing in Indonesia, sustained by a depleted Indian-MORB. Bulletin of Volcanology 80, 5 (2017).

193. Battaglia, A. et al. The magmatic gas signature of Pacaya volcano, with implications for the volcanic $\mathrm{CO}_{2}$ flux from Guatemala. Geochemistry, Geophysics, Geosystems 19, 667-692 (2018).

194. Gerlach, T. M., McGee, K. A. \& Doukas, M. P. Emission rates of $\mathrm{CO}_{2}, \mathrm{SO}_{2}$, and $\mathrm{H}_{2} \mathrm{~S}$, scrubbing, and preeruption excess volatiles at Mount St. Helens, 2004-2005. In: A Volcano Rekindled: The Renewed Eruption of Mount St. Helens, 2004-2006 (eds. W. E. Scott, D. R. Sherrod \& P. H. Stauffer), 554-571 (2008).

195. Aiuppa, A. et al. First volatile inventory for Gorely volcano, Kamchatka. Geophysical Research Letters 39, L06307 (2012).

196. Gunawan, H. et al. New insights into Kawah Ijen's volcanic system from the wet volcano workshop experiment. Geological Society, London, Special Publications 437, 35 (2016).

197. Sutton, A. J. \& Elias, T. One hundred volatile years of volcanic gas studies at the Hawaiian Volcano Observatory. In: Characteristics of Hawaiian Volcanoes. US 
Geological Survey Professional Paper 1801 (eds. M. P. Poland, T. J. Takahashi \& C. M. Landowski), 295-320 (USGS, 2014).

198. Allard, P. Isotope Geochemistry and Origins of Water, Carbon and Sulfur in Volcanic Gases: Rift Zones, Continental Margins and Island Arcs (Paris VII University, 1986).

199. Bani, P. et al. First measurement of the volcanic gas output from Anak Krakatau, Indonesia. Journal of Volcanology and Geothermal Research 302, 237-241 (2015).

200. Lopez, T. et al. Geochemical constraints on volatile sources and subsurface conditions at Mount Martin, Mount Mageik, and Trident Volcanoes, Katmai Volcanic Cluster, Alaska. Journal of Volcanology and Geothermal Research 347, 64-81 (2017).

201. Burton, M. R., Oppenheimer, C., Horrocks, L. A. \& Francis, P. W. Remote sensing of $\mathrm{CO}_{2}$ and $\mathrm{H}_{2} \mathrm{O}$ emission rates from Masaya volcano, Nicaragua. Geology 28, 915-918 (2000).

202. Martin, R. S. et al. A total volatile inventory for Masaya Volcano, Nicaragua. Journal of Geophysical Research 115, 1-12 (2010).

203. Allard, P., Metrich, N. \& Sabroux, J. C. Volatile and magma supply to standard eruptive activity at Merapi volcano, Indonesia. In: EGU General Assembly 2011, Vol. 13, EGU2011-13522 (EGU, 2011).

204. Dzurisin, D. et al. The 2004-2008 dome-building eruption at Mount St. Helens, Washington: epilogue. Bulletin of Volcanology 77, 17 (2015).

205. Taran, Y. A. Geochemistry of volcanic and hydrothermal fluids and volatile budget of the Kamchatka-Kuril subduction zone. Geochimica et Cosmochimica Acta 73, 1067-1094 (2009).

206. Lages J. et al. Volcanic $\mathrm{CO}_{2}$ and $\mathrm{SO}_{2}$ emissions along the Colombia Arc Segment (Northern Volcanic Zone). In: Geophysical Research Abstracts, Vol. 20, EGU20181301 (2018).

207. Bobrowski, N. et al. Plume composition and volatile flux of Nyamulagira volcano, Democratic Republic of Congo, during birth and evolution of the lava lake, 2014-2015. Bulletin of Volcanology 79, 90 (2017).

208. Lyons, J. J. et al. Long period seismicity and very long period infrasound driven by shallow magmatic degassing at Mount Pagan, Mariana Islands. Journal of Geophysical Research: Solid Earth 121, 188-209 (2016).

209. Tulet, P. et al. First results of the Piton de la Fournaise STRAP 2015 experiment: multidisciplinary tracking of a volcanic gas and aerosol plume. Atmospheric Chemistry and Physics 17, 5355-5378 (2017).

210. Aiuppa, A. et al. Gas measurements from the Costa Rica-Nicaragua volcanic segment suggest possible along-arc variations in volcanic gas chemistry. Earth and Planetary Science Letters 407, 134-147 (2014).

211. Maldonado, L. F. M., Inguaggiato, S., Jaramillo, M. T., Valencia, G. G. \& Mazot, A. Volatiles and energy released by Puracé volcano. Bulletin of Volcanology 79, 84 (2017).

212. D'Aleo, R. et al. Preliminary results of a multi-parametric characterization of gas manifestations from volcanoes in west Papua New Guinea. Presented at: Conferenze Nationale Rittmann Giovani Ricercatori, Bari, Italy, 2016.

213. Moussallam, Y. et al. Volcanic gas emissions and degassing dynamics at Ubinas and Sabancaya volcanoes; implications for the volatile budget of the central volcanic zone. Journal of Volcanology and Geothermal Research 343, 181-191 (2017).

214. Granieri, D. et al. Emission of gas and atmospheric dispersion of $\mathrm{SO}_{2}$ during the December 2013 eruption at San Miguel volcano (El Salvador, Central America). Geophysical Research Letters 42, 5847-5854 (2015). 
215. Bani, P. et al. First study of the heat and gas budget for Sirung volcano, Indonesia. Bulletin of Volcanology 79, 60 (2017).

216. Edmonds, M. et al. Excess volatiles supplied by mingling of mafic magma at an andesite arc volcano. Geochemistry, Geophysics, Geosystems 11, Q04005 (2010).

217. Allard, P. et al. Steam and gas emission rate from La Soufriere volcano, Guadeloupe (Lesser Antilles): implications for the magmatic supply during degassing unrest. Chemical Geology 384, 76-93 (2014).

218. GeoNet Database. www.geonet.org.nz (2018).

219. Campion, R. et al. Space- and ground-based measurements of sulphur dioxide emissions from Turrialba Volcano (Costa Rica). Bulletin of Volcanology 74, 1757-1770 (2012).

220. Conde, V. et al. $\mathrm{SO}_{2}$ degassing from Turrialba Volcano linked to seismic signatures during the period 2008-2012. International Journal of Earth Sciences 103, 1983-1998 (2014).

221. Epiard, M. et al. Relationship between diffuse $\mathrm{CO}_{2}$ degassing and volcanic activity. Case study of the Poás, Irazú, and Turrialba Volcanoes, Costa Rica. Frontiers in Earth Science 5 (2017).

222. Martini, F. et al. Geophysical, geochemical and geodetical signals of reawakening at Turrialba volcano (Costa Rica) after almost 150 years of quiescence. Journal of Volcanology and Geothermal Research 198, 416-432 (2010).

223. Vaselli, O. et al. Evolution of fluid geochemistry at the Turrialba volcano (Costa Rica) from 1998 to 2008. Bulletin of Volcanology 72, 397-410 (2010).

224. McGee, K. A., Doukas, M. P., McGimsey, R. G., Wessels, R. L. \& Neal, C. A. Gas emissions from Augustine Volcano, Alaska 1995-2006. EOS Transactions 87, 1687 (2006).

225. López, T. et al. Constraints on magma processes, subsurface conditions, and total volatile flux at Bezymianny Volcano in 2007-2010 from direct and remote volcanic gas measurements. Journal of Volcanology and Geothermal Research 263, 92-107 (2013).

226. Varley, N. R. \& Taran, Y. Degassing processes of Popocatepetl and Volcan de Colima, Mexico. Geological Society Special Publications 213, 263-280 (2003).

227. Hidalgo, S. et al. Evolution of the 2015 Cotopaxi eruption revealed by combined geochemical and seismic observations. Geochemistry Geophysics Geosystems 19, 2087-2108 (2018).

228. Fischer, T. P. et al. The chemical and isotopic composition of fumarolic gases and spring discharges from Galeras Volcano, Colombia. Journal of Volcanology and Geothermal Research 77, 229-253 (1997).

229. Tamburello, G., Hansteen, T. H., Bredemeyer, S., Aiuppa, A. \& Tassi, F. Gas emissions from five volcanoes in northern Chile and implications for the volatiles budget of the Central Volcanic Zone. Geophysical Research Letters 41, 4961-4969 (2014).

230. Menyailov, I. A., Nikitina, L. P., Shapar, V. N. \& Pilipenko, V. P. Temperature increase and chemical change of fumarolic gases at Momotombo Volcano, Nicaragua, in 1982-1985 - are these indicators of possible eruption Journal of Geophysical Research - Solid Earth and Planets 91, 2199-2214 (1986).

231. Hammouya, G. et al. Pre- and syn-eruptive geochemistry of volcanic gases from Soufriere Hills of Montserrat, West Indies. Geophysical Research Letters 25, 3685-3688 (1998).

232. Kusakabe, $\mathrm{M}$. et al. Evolution of $\mathrm{CO}_{2}$ in Lakes Monoun and Nyos, Cameroon, before and during controlled degassing. Geochemical Journal 42, 93-118 (2008). 
233. Dionis, S. M. et al. Diffuse $\mathrm{CO}_{2}$ degassing and volcanic activity at Cape Verde islands, West Africa. Earth, Planets and Space 67, 48 (2015).

234. Zhang, L., Guo, Z., Zhang, M. \& Cheng, Z. Study on soil micro-seepage gas flux in the high temperature geothermal area: an example from the Yangbajing geothermal field, South Tibet. Acta Petrologica Sinica 30, 3612-3626 (2014).

235. Zhang, M. L. et al. Magma-derived $\mathrm{CO}_{2}$ emissions in the Tengchong volcanic field, SE Tibet: implications for deep carbon cycle at intra-continent subduction zone. Journal of Asian Earth Sciences 127, 76-90 (2016).

236. Cheng, Z., Guo, Z., Zhang, M. \& Zhang, L. $\mathrm{CO}_{2}$ flux estimations of hot springs in the Tengchong Cenozoic volcanic field, Yunnan Province, SW China. Acta Petrologica Sinica 28, 1217-1224 (2012).

237. Cheng, Z., Guo, Z., Zhang, M. \& Zhang, L. Carbon dioxide emissions from Tengchong Cenozoic volcanic field, Yunnan Province, SW China. Acta Petrologica Sinica 30, 3657-3670 (2014).

238. Guo, Z., Zhang, M., Cheng, Z., Zhang, L. \& Liu, J. Fluxes and genesis of greenhouse gases emissions from typical volcanic fields in China. Acta Petrologica Sinica 30, 3467-3480 (2014).

239. Zhang, M. et al. Greenhouse gases flux estimation of hot springs in Changbaishan volcanic field, NE China. Acta Petrologica Sinica 24, 2898-2904 (2011).

240. Sun, Y. \& Guo, Z. $\mathrm{CO}_{2}$ diffuse emission from maar lake: an example in Changbai volcanic field, NE China. Journal of Volcanology and Geothermal Research 349, 146-162 (2017).

241. Galindo, I. et al. Emision difusa de dioxido de carbono en el volcan Irazu, Costa Rica. Carbon dioxide emissions at Irazu Volcano, Costa Rica. Revista Geologica de America Central 30, 157-165 (2004).

242. Liegler, A. Diffuse $\mathrm{CO}_{2}$ Degassing and the Origin of Volcabic Gas Variability from Rincon de la Vieja, Miravalles and Tenorio Volcanoes, Master of Science in Geology thesis, Michigan Technological University (2016).

243. Melián, G. V. et al. Emisión difusa de $\mathrm{CO}_{2}$ y actividad volcánica en el volcán Poás, Costa Rica. Revista Geológica de América Central 43, 147-170 (2010).

244. Padron, E. et al. Diffuse $\mathrm{CO}_{2}$ emission rate from Pululahua and the lake-filled Cuicocha calderas, Ecuador. Journal of Volcanology and Geothermal Research 176, 163-169 (2008).

245. Padron, E. et al. Fumarole/plume and diffuse $\mathrm{CO}_{2}$ emission from Sierra Negra caldera, Galapagos archipelago. Bulletin of Volcanology 74, 1509-1519 (2012).

246. Salazar, J. M. L. et al. Spatial and temporal variations of diffuse $\mathrm{CO}_{2}$ degassing at the Santa Ana-Izalco-Coatepeque volcanic complex, El Salvador, Central America. Special Paper - Geological Society of America 375, 135-146 (2004).

247. López, D. L., Ransom, L., Pérez, N. M., Hernández, P. A. \& Monterrosa, J. Dynamics of diffuse degassing at Ilopango Caldera, El Salvador. In: Special Paper of the Geological Society of America, Vol. 375 (eds. W. I. Rose et al.), 191-202 (Geological Society of America, 2004).

248. Hutchison, W., Mather, T. A., Pyle, D. M., Biggs, J. \& Yirgu, G. Structural controls on fluid pathways in an active rift system: a case study of the Aluto volcanic complex. Geosphere 11, 542-562 (2015).

249. Brombach, T., Hunziker, J. C., Chiodini, G., Cardellini, C. \& Marini, L. Soil diffuse degassing and thermal energy fluxes from the southern Lakki plain, Nisyros (Greece). Geophysical Research Letters 28, 69-72 (2001). 
250. Caliro, S. et al. Recent activity of Nisyros volcano (Greece) inferred from structural, geochemical and seismological data. Bulletin of Volcanology 67, 358-369 (2005).

251. D'Alessandro, W. et al. Diffuse and focused carbon dioxide and methane emissions from the Sousaki geothermal system, Greece. Geophysical Research Letters 33, 5 (2006).

252. Parks, M. M. et al. Distinguishing contributions to diffuse $\mathrm{CO}_{2}$ emissions in volcanic areas from magmatic degassing and thermal decarbonation using soil gas Rn-222delta C-13 systematics: application to Santorini volcano, Greece. Earth and Planetary Science Letters 377, 180-190 (2013).

253. D’Alessandro, W., Brusca, L., Kyriakopouios, K., Michas, G. \& Papadakis, G. Methana, the westernmost active volcanic system of the south Aegean arc (Greece): insight from fluids geochemistry. Journal of Volcanology and Geothermal Research 178, 818-828 (2008).

254. Fridriksson, T. et al. $\mathrm{CO}_{2}$ emissions and heat flow through soil, fumaroles, and steam heated mud pools at the Reykjanes geothermal area, SW Iceland. Applied Geochemistry 21, 1551-1569 (2006).

255. Hernandez, P. et al. Diffuse volcanic degassing and thermal energy release from Hengill volcanic system, Iceland. Bulletin of Volcanology 74, 2435-2448 (2012).

256. Toutain, J. P. et al. Structure and $\mathrm{CO}_{2}$ budget of Merapi volcano during inter-eruptive periods. Bulletin of Volcanology 71, 815-826 (2009).

257. Carapezza, M. L. et al. Diffuse $\mathrm{CO}_{2}$ soil degassing and $\mathrm{CO}_{2}$ and $\mathrm{H}_{2} \mathrm{~S}$ concentrations in air and related hazards at Vulcano Island (Aeolian arc, Italy). Journal of Volcanology and Geothermal Research 207, 130-144 (2011).

258. Chiodini, G., Frondini, F. \& Raco, B. Diffuse emission of $\mathrm{CO}_{2}$ from the Fossa Crater, Vulcano Island (Italy). Bulletin of Volcanology 58, 41-50 (1996).

259. Inguaggiato, $\mathrm{S}$. et al. Total $\mathrm{CO}_{2}$ output from Vulcano island (Aeolian Islands, Italy). Geochemistry, Geophysics, Geosystems 13, Q02012 (2012).

260. Granieri, D. et al. Correlated increase in $\mathrm{CO}_{2}$ fumarolic content and diffuse emission from La Fossa crater (Vulcano, Italy): evidence of volcanic unrest or increasing gas release from a stationary deep magma body? Geophysical Research Letters 33, L13316 (2006).

261. D' Alessandro, W. et al. Chemical and isotopic characterization of the gases of Mount Etna (Italy). Journal of Volcanology and Geothermal Research 78, 65-76 (1997).

262. Giammanco, S., Bellotti, F., Groppelli, G. \& Pinton, A. Statistical analysis reveals spatial and temporal anomalies of soil $\mathrm{CO}_{2}$ efflux on Mount Etna volcano (Italy). Journal of Volcanology and Geothermal Research 194, 1-14 (2010).

263. Camarda, M., De Gregorio, S. \& Gurrieri, S. Magma-ascent processes during 2005-2009 at Mt Etna inferred by soil $\mathrm{CO}_{2}$ emissions in peripheral areas of the volcano. Chemical Geology 330, 218-227 (2012).

264. De Gregorio, S. \& Camarda, M. A novel approach to estimate the eruptive potential and probability in open conduit volcanoes. Scientific Reports 6, 30471 (2016).

265. Melian, G. et al. Diffuse and visible emission of $\mathrm{CO}_{2}$ from Etna Volcano, Italy. American Geophysical Union, Fall Meeting \#V21D-202 (2009).

266. Inguaggiato, $\mathrm{S}$. et al. $\mathrm{CO}_{2}$ output discharged from Stromboli Island (Italy). Chemical Geology 339, 52-60 (2013).

267. Granieri, D., Chiodini, G., Avino, R. \& Caliro, S. Carbon dioxide emission and heat release estimation for Pantelleria Island (Sicily, Italy). Journal of Volcanology and Geothermal Research 275, 22-33 (2014). 
268. Favara, R., Giammanco, S., Inguaggiato, S. \& Pecoraino, G. Preliminary estimate of $\mathrm{CO}_{2}$ output from Pantelleria Island volcano (Sicily, Italy): evidence of active mantle degassing. Applied Geochemistry 16, 883-894 (2001).

269. Frondini, F. et al. Diffuse $\mathrm{CO}_{2}$ degassing at Vesuvio, Italy. Bulletin of Volcanology 66, 642-651 (2004).

270. Granieri, D. et al. Level of carbon dioxide diffuse degassing from the ground of Vesuvio: comparison between extensive surveys and inferences on the gas source. Annals of Geophysics 56, doi:10.4401/ag-6455 (2013).

271. Aiuppa, A. et al. First observations of the fumarolic gas output from a restless caldera: implications for the current period of unrest (2005-2013) at Campi Flegrei. Geochemistry Geophysics Geosystems 14, 4153-4169 (2013).

272. Pecoraino, G. et al. Total $\mathrm{CO}_{2}$ output from Ischia Island volcano (Italy). Geochemical Journal 39, 451-458 (2005).

273. Chiodini, G. et al. Fumarolic and diffuse soil degassing west of Mount Epomeo, Ischia, Italy. Journal of Volcanology and Geothermal Research 133, 291-309 (2004).

274. Rogie, J. D., Kerrick, D. M., Chiodini, G. \& Frondini, F. Flux measurements of nonvolcanic $\mathrm{CO} 2$ emission from some vents in central Italy. Journal of Geohysical Research: Solid Earth 105, 8435-8445 (2000).

275. Chiodini, G. et al. Geochemical evidence for and characterization of $\mathrm{CO}_{2}$ rich gas sources in the epicentral area of the Abruzzo 2009 earthquakes. Earth and Planetary Science Letters 304, 389-398 (2011).

276. Frondini, F., Caliro, S., Cardellini, C., Chiodini, G. \& Morgantini, N. Carbon dioxide degassing and thermal energy release in the Monte Amiata volcanic-geothermal area (Italy). Applied Geochemistry 24, 860-875 (2009).

277. Costa, A. et al. A shallow-layer model for heavy gas dispersion from natural sources: application and hazard assessment at Caldara di Manziana, Italy. Geochemistry, Geophysics, Geosystems 9, Q03002 (2008).

278. Quattrocchi, F. et al. Continuous/discrete geochemical monitoring of $\mathrm{CO}_{2}$ natural analogues and of diffuse degassing structures (DDS): hints for $\mathrm{CO}_{2}$ storage sites geochemical monitoring protocol. In: Greenhouse Gas Control Technologies 9, Vol. 1 Energy Procedia (eds. J. Gale, H. Herzog \& J. Braitsch), 2135-2142 (Elsevier, 2009).

279. Hernandez, P. A. et al. Diffuse emission of $\mathrm{CO}_{2}$ from Miyakejima volcano, Japan. Chemical Geology 177, 175-185 (2001).

280. Hernandez, P. A. et al. Diffuse emission of $\mathrm{CO}_{2}$ from Showa-Shinzan, Hokkaido, Japan; a sign of volcanic dome degassing. Pure and Applied Geophysics 163, 869-881 (2006).

281. Hernandez, P. A. et al. Carbon dioxide degassing by advective flow from Usu volcano, Japan. Science 292, 83-86 (2001).

282. Hirabayashi, J. \& Mizuhashi, M. The discharge rate of volatiles from KusatsuShirane volcano, Japan. Report of 4th Joint Observation of Kusatsu-Shirane Volcano, 167-174 (2004).

283. Shimoike, Y., Kazahaya, K. \& Shinohara, H. Soil gas emission of volcanic $\mathrm{CO}_{2}$ at Satsuma-Iwojima Volcano, Japan. Earth, Planets and Space 54, 239-247 (2002).

284. Saito, M., Matsushima, T., Matsuwo, N. \& Shimizu, H. Observation $\mathrm{SO}_{2}$ and $\mathrm{CO}_{2}$ fluxes in and around the active crater of Aso Nakadake Volcano. In: Science Reports of the Kyushu University, Department of Earth and Planetary Sciences, Vol. 22 (2007).

285. Notsu, K., Mori, T., Do Vale, S. C., Kagi, H. \& Ito, T. Monitoring quiescent volcanoes by diffuse $\mathrm{CO}_{2}$ degassing; case study of Mt. Fuji, Japan. Pure and Applied Geophysics 163, 825-835 (2006). 
286. Hernandez, P. A., Mori, T., Padron, E., Sumino, H. \& Perez, N. Carbon dioxide emission from Katanuma volcanic lake, Japan. Earth, Planets and Space 63, 1151-1156 (2011).

287. Notsu, K. et al. Diffuse $\mathrm{CO}_{2}$ efflux from Iwojima Volcano, Izu-Ogasawara Arc, Japan. Journal of Volcanology and Geothermal Research 139, 147-161 (2005).

288. Robertson, E. et al. Diffuse degassing at Longonot volcano, Kenya: implications for $\mathrm{CO}_{2}$ flux in continental rifts. Journal of Volcanology and Geothermal Research 327, 208-222 (2016).

289. Werner, C., Christenson, B., Scott, B., Britten, K. \& Kilgour, G. Monitoring CO2 emissions at White Island volcano, New Zealand: evidence for total decreases in magmatic mass and heat output. In: Water Rock Interaction, Eleventh Symposium (eds. R. Wanty, \& R. R. Seal), 223-226 (A.A. Balkema Publishers, 2004).

290. Harvey, M. C. et al. Heat flux from magmatic hydrothermal systems related to availability of fluid recharge. Journal of Volcanology and Geothermal Research 302, 225-236 (2015).

291. Salazar, J. M. L. et al. Diffuse emission of carbon dioxide from Cerro Negro Volcano, Nicaragua, Central America. Geophysical Research Letters 28, 4275-4278 (2001).

292. Harvey, M. C., White, P. J., Kenzie, K. M. \& Lovelock, B. G. Results from soil $\mathrm{CO}_{2}$ flux and shallow temeperature survey at the San Jacinto-Tizate geothermal power project. In: Nicaragua in New Zealand Geothermal Workshop 2011, 1-8 (University of Auckland, 2011).

293. Lewicki, J. L. et al. Comparative soil $\mathrm{CO}_{2}$ flux measurements and geostatistical estimation methods on Masaya volcano, Nicaragua. Bulletin of Volcanology $\mathbf{6 8}$, 76-90 (2005).

294. Arpa, M. C. et al. Geochemical evidence of magma intrusion inferred from diffuse $\mathrm{CO}_{2}$ emissions and fumarole plume chemistry: the 2010-2011 volcanic unrest at Taal Volcano, Philippines. Bulletin of Volcanology 75, 747 (2013).

295. Viveiros, F. et al. Soil $\mathrm{CO}_{2}$ emissions at Furnas volcano, Sao Miguel Island, Azores archipelago: Volcano monitoring perspectives, geomorphologic studies, and land use planning application. Journal of Geophysical Research: Solid Earth 115, B12208 (2010).

296. Andrade, C., Viveiros, F., Cruz, J. V., Coutinho, R. \& Silva, C. Estimation of the $\mathrm{CO}_{2}$ flux from Furnas volcanic Lake (São Miguel, Azores). Journal of Volcanology and Geothermal Research 315, 51-64 (2016).

297. Frunzeti, N. Geogenic Emissions of Greenhouse Gases in the Southern Part of the Eastern Carpathians. PhD thesis (Babeș-Bolyai University, 2013).

298. Frunzeti, N. \& Baciu, C. Diffuse $\mathrm{CO}_{2}$ emission at Santa Ana lake-filled crater (Eastern Carpathians, Romania). Procedia Environmental Sciences, 14, 188-194 (2012).

299. Inguaggiato, S., Cardellini, C., Taran, Y. \& Kalacheva, E. The $\mathrm{CO}_{2}$ flux from hydrothermal systems of the Karymsky volcanic Centre, Kamchatka. Journal of Volcanology and Geothermal Research 346, 1-9 (2017).

300. Hernandez, P. A. et al. Analysis of long- and short-term temporal variations of the diffuse $\mathrm{CO}_{2}$ emission from Timanfaya volcano, Lanzarote, Canary Islands. Applied Geochemistry 27, 2486-2499 (2012).

301. Perez, P. H. et al. Carbon dioxide emissions from soils at Hakkoda, north Japan. Journal of Geophysical Research 108, 9 (2003).

302. Melian, G. et al. A magmatic source for fumaroles and diffuse degassing from the summit crater of Teide Volcano (Tenerife, Canary Islands): a geochemical evidence for the 2004-2005 seismic-volcanic crisis. Bulletin of Volcanology 74, 1465-1483 (2012). 
303. Hernandez, P. A. et al. Geochemical evidences of seismo-volcanic unrests at the NW rift zone of Tenerife, Canary Islands, inferred from diffuse $\mathrm{CO}_{2}$ emission. Bulletin of Volcanology 79, 30 (2017).

304. Melian, G. et al. Spatial and temporal variations of diffuse $\mathrm{CO}_{2}$ degassing at $\mathrm{El}$ Hierro volcanic system: relation to the 2011-2012 submarine eruption. Journal of Geophysical Research: Solid Earth 119, 6976-6991 (2014).

305. Padron, E. et al. Dynamics of diffuse carbon dioxide emissions from Cumbre Vieja volcano, La Palma, Canary Islands. Bulletin of Volcanology 77, 28 (2015).

306. Lan, T. F. et al. Compositions and flux of soil gas in Liu-Huang-Ku hydrothermal area, northern Taiwan. Journal of Volcanology and Geothermal Research 165, 32-45 (2007).

307. Wen, H.-Y. et al. Soil $\mathrm{CO}_{2}$ flux in hydrothermal areas of the Tatun Volcano Group, Northern Taiwan. Journal of Volcanology and Geothermal Research 321, 114-124 (2016).

308. Nisi, B., Vaselli, O., Marchev, P. \& Tassi, F. Diffuse $\mathrm{CO}_{2}$ soil flux measurements at the youngest volcanic system in Bulgaria: the 12.2 Ma old Kozhuh cryptodome. Acta Vulcanologica 25, 169-178 (2013).

309. Bergfeld, D., Goff, F. \& Janik, C. J. Elevated carbon dioxide flux at the Dixie Valley geothermal field, Nevada; relations between surface phenomena and the geothermal reservoir. Chemical Geology 177, 43-66 (2001).

310. Bergfeld, D., Evans, W. C., Howle, J. F. \& Farrar, C. D. Carbon dioxide emissions from vegetation-kill zones around the resurgent dome of Long Valley caldera, eastern California, USA. Journal of Volcanology and Geothermal Research 152, 140-156 (2006).

311. Bergfeld, D., Evans, W. C., Howle, J. F. \& Hunt, A. G. Magmatic gas emissions at Holocene volcanic features near Mono Lake, California, and their relation to regional magmatism. Journal of Volcanology and Geothermal Research 292, 70-83 (2015).

312. Evans, W. C., Bergfeld, D., McGimsey, R. G. \& Hunt, A. G. Diffuse gas emissions at the Ukinrek Maars, Alaska: implications for magmatic degassing and volcanic monitoring. Applied Geochemistry 24, 527-535 (2009).

313. Sorey, M. L., Werner, C., McGimsey, R. G. \& Evans, W. C. Hydrothermal Activity and Carbon Dioxide Discharge at Shrub and Upper Klawasi Mud Volcanoes, Wrangell Mountains, Alaska. Water-Resources Investigations Report 00-4207 (USGS, 2000).

314. Werner, C. et al. Volatile emissions and gas geochemistry of Hot Spring Basin, Yellowstone National Park, USA. Journal of Volcanology and Geothermal Research 178, 751-762 (2008).

315. Bergfeld, D., Evans, W. C., Lowenstern, J. B. \& Hurwitz, S. Carbon dioxide and hydrogen sulfide degassing and cryptic thermal input to Brimstone Basin, Yellowstone National Park, Wyoming. Chemical Geology 330, 233-243 (2012).

316. Lin, P., Deering, C. D., Werner, C. \& Torres, C. Origin and quantification of diffuse $\mathrm{CO}_{2}$ and $\mathrm{H}_{2} \mathrm{~S}$ emissions at Crater Hills, Yellowstone National Park. Journal of Volcanology and Geothermal Research, 377, 117-130 (2019).

317. Marty, B., Alexander, C. M. O. \& Raymond, S. N. Primordial origins of Earth's carbon. In: Reviews in Mineralogy and Geochemistry, Vol. 75, 149-181 (Mineralogical Society of America, 2013). 